\title{
Characterization of a fluvial aquifer at a range of depths and scales: the Triassic St Bees Sandstone Formation, Cumbria, UK
}

\author{
${\text { Giacomo } \text { Medici }^{1} \text { - L. J. } \text { West }^{1} \cdot \text { N. P. Mountney }}^{1}$
}

Received: 7 February 2017 / Accepted: 15 October 2017 / Published online: 10 November 2017

(C) The Author(s) 2017. This article is an open access publication

\begin{abstract}
Fluvial sedimentary successions represent porous media that host groundwater and geothermal resources. Additionally, they overlie crystalline rocks hosting nuclear waste repositories in rift settings. The permeability characteristics of an arenaceous fluvial succession, the Triassic St Bees Sandstone Formation in England (UK), are described, from core-plug to well-test scale up to $\sim 1 \mathrm{~km}$ depth. Within such lithified successions, dissolution associated with the circulation of meteoric water results in increased permeability $\left(K \sim 10^{-1}-10^{0} \mathrm{~m} /\right.$ day $)$ to depths of at least $150 \mathrm{~m}$ below ground level (BGL) in aquifer systems that are subject to rapid groundwater circulation. Thus, contaminant transport is likely to occur at relatively high rates. In a deeper investigation (> $150 \mathrm{~m}$ depth), where the aquifer has not been subjected to rapid groundwater circulation, well-test-scale hydraulic conductivity is lower, decreasing from $K \sim 10^{-2} \mathrm{~m} /$ day at 150 $400 \mathrm{~m} \mathrm{BGL}$ to $10^{-3} \mathrm{~m} /$ day down-dip at $\sim 1 \mathrm{~km}$ BGL, where the pore fluid is hypersaline. Here, pore-scale permeability becomes progressively dominant with increasing lithostatic load. Notably, this work investigates a sandstone aquifer of fluvial origin at investigation depths consistent with highly enthalpy geothermal reservoirs $(\sim 0.7-1.1 \mathrm{~km})$. At such depths, intergranular flow dominates in unfaulted areas with only minor contribution by bedding plane fractures. However, extensional faults represent preferential flow pathways, due to
\end{abstract}

Electronic supplementary material The online version of this article (https://doi.org/10.1007/s10040-017-1676-z) contains supplementary material, which is available to authorized users.

Giacomo Medici

eegm@leeds.ac.uk

1 School of Earth and Environment, University of Leeds, Woodhouse Lane, Leeds, W Yorkshire LS2 9JT, UK presence of high connective open fractures. Therefore, such faults may (1) drive nuclear waste contaminants towards the highly permeable shallow ( $<150 \mathrm{~m} \mathrm{BGL}$ ) zone of the aquifer, and (2) influence fluid recovery in geothermal fields.

Keywords Fluvial deposits $\cdot$ Scale effects $\cdot$ Flow heterogeneity $\cdot$ Faults $\cdot$ UK

\section{Introduction}

Fluvial deposits form thick sedimentary successions (> $0.5 \mathrm{~km}$ ) in basins for which accommodation was generated in response to extensional, compressional and strike slip tectonics, as well as thermal subsidence (Bosellini 1989; Carvalho and Vesely 2017; Ielpi and Ghinassi 2015; Waugh 1973). Thick accumulations of fluvial sediments of Triassic age are especially widespread, being represented in South and North America, Europe, Africa, Asia and Australia; many such examples form the fill of rift valleys that developed due to the break-up of Pangaea (Walker 1967; Waugh 1973; Ziegler 1982). Notably, fluvial (sandstone) and lacustrine (shale, evaporite) deposits in rift settings commonly overlie crystalline basement rocks (as in this study example). Cyclical fragmentation of cratons over geological time scales places these sediments, which form rift-basin fills, upon relatively low permeability meta-igneous basement rocks. In some basins, these basement rocks are used to host nuclear waste repositories (Berglund et al. 2009; Michie 1996; Waugh 1973). Furthermore, fluvial deposits represent porous media, which can serve as important hosts for hydrocarbon and geothermal resources (McKie and Williams 2009; Ruggeri and Gianelli 1999); additionally, they serve as important groundwater aquifers (Tellam and Barker 2006; Tellam 2004). 
This study presents a quantitative analysis to show how sedimentary and tectonic heterogeneities influence fluid flow in a fluvial sandstone aquifer at a variety of scales, up to $1,100 \mathrm{~m}$ below the ground surface. Assessment of groundwater behavior at such depths is important in geoscience since depth of well screens for water abstraction is typically $<100 \mathrm{~m}$ below ground level (BGL) in the major European and American industrial cities (De Simone 2008; Tellam and Barker 2006; Toccalino et al. 2010; Worthington et al. 2016), whereas depth intervals associated with nuclear waste repositories are typically $200-1,100 \mathrm{~m}$ BGL (Martin and Christiansson 2009; Min et al. 2004; Tsang et al. 2012; Voss and Andersson 1993). Thus, the proposed characterization allows investigation of the role of a range of geological discontinuities (e.g., stratabound joints and faults) which potentially establish hydraulic connection between a nuclear waste repository and aquifers exploited for civil use (Tsang et al. 2016). Furthermore, exploitation of high enthalpy geothermal reservoirs typically involves extraction of fluids at depths ranging from $\sim 700$ to $1,100 \mathrm{~m}$ from sandstone reservoir rocks in areas which are characterized by high geothermal gradient $\left(\sim 200{ }^{\circ} \mathrm{C} / \mathrm{km}\right)$. For example, fluids are extracted at such depths in the high enthalpy geothermal fields of the eastern margin of the Tyrrhenian Sea (Aldinucci et al. 2008; Ruggeri and Gianelli 1999; Truesdell and White 1973).

However, fluvial sedimentary successions also represent productive hydrocarbon reservoirs in onshore regions of North Europe, North Africa, North America, South America and in Middle East at depths ranging from $\sim 1,000$ to $\sim 2,000 \mathrm{~m}$ (Bourquin et al. 2010; Nguyen et al. 2013; Sadooni and Alsharhan 2004; Selley 1978). Investigation depths of > 150 m BGL are sufficient to avoid 'karstic' features common at shallower depths (Worthington et al. 2016). Hence, petrohydraulic characterization at these depths (>150 m BGL) can also contribute to enhance recovery in hydrocarbon reservoirs, assessing, on analogous successions, compartmentalization effects made by sedimentary structures. Thus, the research presented here may find application in (1) safeguarding water supply from wells, (2) influencing the design of deep geological repositories, and (3) enhancing recovery in geothermal and hydrocarbon reservoirs (Bianchi et al. 2015; Gellasch et al. 2013; Huysmans and Dassargues 2006; Olivarius et al. 2015; Worthington et al. 2016; Zheng et al. 2000).

Previous hydro-geophysical characterization studies of sandstone aquifers have mostly focused on the first $150 \mathrm{~m}$ below the ground surface, providing information on the effects of bedding parallel fractures and faults on water flow (Gellasch et al. 2013; Lo et al. 2014; Runkel et al. 2006; Hitchmough et al. 2007; Medici et al. 2016). Several petrohydraulic studies conducted on sandstone lithotypes (including fluvial deposits) have been undertaken on successions at depths $\geq 1,000 \mathrm{~m}$ using data from hydrocarbon extraction fields (e.g., Baas et al. 2007; Corbett et al. 2012; Zheng et al. 2000). However, multi-disciplinary studies that investigate the hydraulic properties of fluvial aquifers (and sandstone aquifers more generally) at different scales are lacking for successions at depths of investigation of 150-1,100 m BGL.

This research investigates a specific fluvial aquifer, the Triassic St Bees Sandstone Formation, Cumbria, UK (Fig. 1a), which has been the object of recent studies of sedimentary heterogeneities (e.g., Medici et al. 2015). The St Bees Sandstone Formation is well suited to the study of aquifer heterogeneities since it accumulated in the rapidly subsiding $(210 \mathrm{~m} / \mathrm{Ma}$ ) eastern Irish Sea Basin (Akhurst et al. 1998; Chadwick et al. 1994). High rates of subsidence allowed accumulation and preservation of fine-grained argillaceous lithotypes (e.g. mudstone) typical of deposition in fluvial overbank settings in response to nonconfined flood events (Medici et al. 2015). Such overbank deposits tend to be preferentially preserved in basins subject to rapid rates of subsidence whereby channel emplacement by avulsion does not fully rework them (Colombera et al. 2013).

Fine-grained fluvial deposits of overbank origin represent potential low-permeability layers that are particularly well preserved in this sedimentary basin. Furthermore, the St Bees Sandstone aquifer is characterized by stratabound-type fractures (sensu Odling et al. 1999; Rustichelli et al. 2013, 2016), which are particularly pervasive in this aquifer due to the layered nature of sandstone beds that possess high mechanical resistance (Bell 1992; Daw et al. 1974). Thus, the St Bees Sandstone aquifer represents an optimum laboratory to test a wide range of aquifer heterogeneities of both tectonic (e.g., vertical joints, normal faults) and sedimentary origin (e.g., mudstone and very fine-grained sandstone layers; Bell 1992; Knott 1994; Medici et al. 2015). Additionally, parts of the St Bees Sandstone aquifer were drilled in the early 1990s to depths ranging from 150 to $1,100 \mathrm{~m}$ as part of the planning for the proposed Sellafield nuclear waste repository (Appleton 1993; Michie 1996). Thus, this area offers the opportunity to re-analyze unpublished hydrogeological data (pumping tests and fluid conductivity and temperature logs), which were acquired during the 1990s. Such data sets can be integrated with hydro-geophysical (flow-logging, acoustic televiewer) and petrophysical data (NMR, permeability tests, SEM, petrographic microscope) to compare core-plug and well-testscale properties.

The aim of this research is to quantitatively characterize the impact of geological heterogeneities in fluvial types of aquifer up to $1,100 \mathrm{~m}$ BGL. Specific research objectives are as follows: (1) to document the petrophysical properties of features that serve as sedimentary flow heterogeneities in the St Bees Sandstone aquifer; (2) to identify the respective roles of matrix, bedding-plane fractures and other tectonic structures (stratabound joints and faults) on conducting flow at a range of scales (core-plug vs. well-test scale) and depths (up to 1,100 m BGL) under pumped conditions; and (3) to determine 
and interpret horizontal and vertical permeability anisotropy $\left(K_{\mathrm{h}} / K_{\mathrm{v}}\right)$ values occurring in this fluvial aquifer type at both core-plug and well-test scales.

\section{Hydrogeological setting}

The Sherwood Sandstone Group (Lower Triassic) is a continental succession that has long been ascribed to a mixed fluvial and aeolian origin (e.g., Mountney and Thompson 2002; Tellam and Barker 2006; Thompson 1970; Turner 1981). This sandstone-dominated succession represents the UK's second most important aquifer, covering $25 \%$ of the total licensed volume of groundwater abstractions in the country (Abesser and Lewis 2015; Binley et al. 2002; Bricker et al. 2012). Contamination has been detected in the aquifer at relatively shallow ( $<\sim 150 \mathrm{~m} \mathrm{BGL})$ depths due to agricultural activity, and the release of industrial waste and sewage in urban areas (Barrett et al. 1999; Bottrell et al. 2008; Bloomfield et al. 2001; Cassidy et al. 2014; Lawrence et al. 2006; Rivett et al. 2012); furthermore, the Sherwood Sandstone Group hosts important hydrocarbon resources onshore in Dorset $(\sim 1,500 \mathrm{~m}$ BGL), as well as in the Irish Sea and in the North Sea (McKie and Williams 2009; McKie and Shannon 2011).

The Sherwood Sandstone Group of West Cumbria was deposited on the edge of the rift basin of the eastern Irish Sea Basin, which itself represents a half-graben bounded at its margin by extensional faults that divide it from the Lake District palaeo-horst (Fig. 1b). In this region, the Sherwood Sandstone Group attains a typical thickness of 1,300 m (Fig. 1c; Akhurst et al. 1998; Jones and Ambrose 1994; Nirex 1993a, 1997) and is formally divided into three different formations: the St Bees, Calder and Ormskirk Sandstone formations (Barnes et al. 1994; Holliday et al. 2008). The study area $(\sim 3.5 \times 20 \mathrm{~km}$ wide $)$ is located in the St Bees-Sellafield area in NW England (Fig. 1), and is covered by a network of wells which are typically $\sim 3 \mathrm{~km}$ spaced. Here, the St Bees Sandstone aquifer, which represents the focus of this study, is covered by glacial Quaternary deposits, which are characterized by an interbedded succession of clays, silts, sands and gravels (McMillan et al. 2000; Merritt and Auton 2000). Aquifer recharge mostly arises from streams (Calder and Ehin rivers) which run off the relatively impermeable rocks of the Lake District Massif to the east (Heathcote et al. 1996; McMillan et al. 2000). For this study, the shallow $(<150 \mathrm{~m}$ BGL) hydro-geophysical characterization of the St Bees Sandstone aquifer ( $\sim 500 \mathrm{~m}$ thick) has been undertaken in the northern sector of the study area, whereas hydro-geophysical data of the deep St Bees Sandstone aquifer (200-1,100 m BGL) are from the southern Sellafield area (Fig. 1b). Here, a deep geological repository was planned during the 1990s and a series of boreholes were drilled between fault-bounded blocks of the rift basin in the east, and the coastline to the west
(Sutton 1996). The combination of the westward dip of the beds $\left(5-20^{\circ}\right)$ and down-throw associated with normal faulting places the St Bees Sandstone aquifer at greater depths, beneath increasing thicknesses of the overlying Calder and Ormskirk Sandstone formations, towards the west (Fig. 1d).

The St Bees Sandstone aquifer is dominated by fine-tomedium-grained sandstone of fluvial origin that passes upwards into the overlying aeolian-dominated succession (Jones and Ambrose 1994; Holliday et al. 2008). The Brockram Formation, which consists of low-permeability deposits of Permian age (conglomerate with a silty matrix, evaporites and shale) underlies the St Bees Sandstone aquifer forming an aquitard unit (Allen et al. 1997; Streetly et al. 2000).

The St Bees Sandstone Formation is characterized by fluvial deposits of a braided-fluvial system (Jones and Ambrose 1994; Medici et al. 2015). The St Bees Sandstone Formation is divided into two members: the North Head and the overlying South Head members (sensu Medici et al. 2015). The two members are differentiated based on the abundance of finegrained mudstone layers that range in grain size from clay to coarse silt (Jones and Ambrose 1994; Nirex 1997). The basal $35 \mathrm{~m}$ of the lower North Head Member is characterized by an alternation of fine-grained sandstone and mudstone beds. This basal aquifer passes upward into a succession dominated by sandstone, with mudstone interlayers representing only 25 and $5 \%$ of the overall succession in the upper North Head and South Head members, respectively (Barnes et al. 1994; Jones and Ambrose 1994; Nirex 1997). Tectonic heterogeneities, which characterize the UK Sherwood Sandstone Group both where it is of fluvial and aeolian origin, are represented by extensional faults and vertical joints in West Cumbria (Allen et al. 1998; Ameen 1995; Chadwick 1997). Bedbound vertical joints form a pervasive fracturing network; the joints terminate against bedding-parallel fractures. Locally, normal faults complicate the fracturing pattern; such faults are characterized by higher occurrence of open fractures with respect to deformation bands in the fluvial deposits of the St Bees Sandstone Formation. By contrast, fault zones in the aeolian Calder and Ormskirk Sandstone formations are more abundant in deformation bands rather than open fractures (Knott 1994).

Deposits of the Sherwood Sandstone Group across the UK yield typical matrix porosity values of $15-30 \%$ and matrix hydraulic conductivity values of $0.1-8.0 \mathrm{~m} /$ day (e.g., Allen et al. 1997; Bloomfield et al. 2006; Pokar et al. 2006). However, the St Bees Sandstone Formation shows relatively low porosity $\left(\phi_{\text {median }}=15.0 \%\right)$ and core-plug scale permeability $\left(K_{\text {median }}=4.0 \times 10^{-3} \mathrm{~m} /\right.$ day $)$ values compared to the entire Sherwood Sandstone Group. The St Bees Sandstone Formation in the southern part of the Egremont-Sellafield plain is overlain by the aeolian deposits of the Calder and Ormskirk Sandstone formations which are more porous 


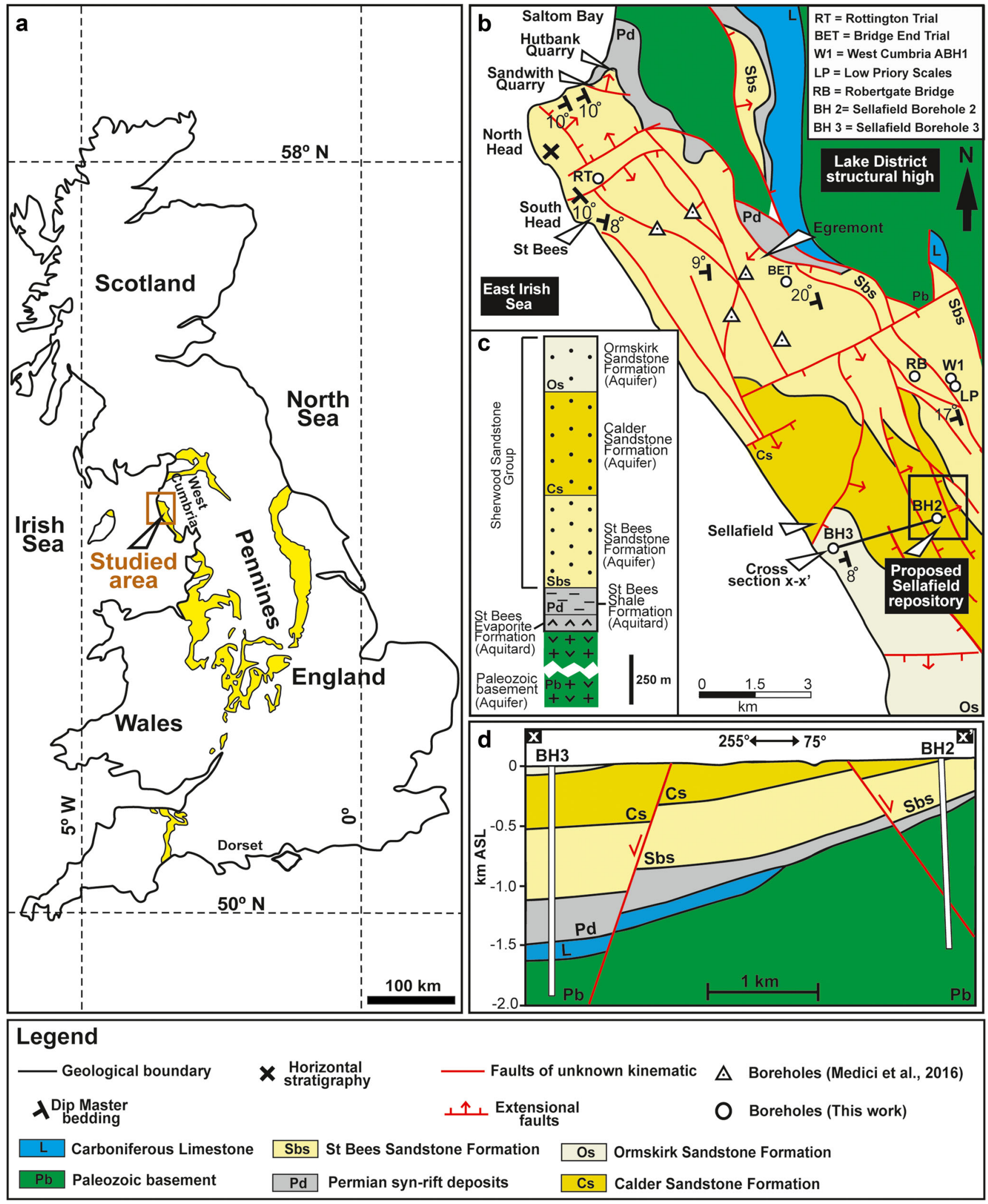

Fig. 1 a Great Britain (England, Wales and Scotland within the UK) with indication of the study area (orange box); the yellow areas delineate the Sherwood Sandstone Group in England. b Geological map of West Cumbria (England) in the St Bees-Sellafield area showing wells referred to in this study, c Stratigraphic column of the field site and hydraulic behavior of the geological formations, $\mathbf{d}$ geological cross-sections of the study area (redrawn from British Geological Survey 2016) 
$\left(\phi_{\text {median }}=19.5 \%\right)$ and permeable $\left(K_{\text {median }}=3.0 \times 10^{-2} \mathrm{~m} /\right.$ day). Wireline logs in the Triassic reservoirs of the Irish and North Sea off-shore areas confirm that the rock matrix is more porous and permeable in these aeolian deposits than in the fluvial facies (Ambrose et al., 2014: Olivarius et al. 2015).

Historically, pumping tests undertaken at shallow $(<150 \mathrm{~m}$ BGL) depths yield relatively high transmissivity $(T)$ values throughout the St Bees-Sellafield coastal plain (Fig. 1) in both wells penetrating the fluvial ( $n=9 ; T=30-700 \mathrm{~m}^{2} /$ day) and aeolian ( $n=3 ; T=100-220 \mathrm{~m}^{2} /$ day) deposits (Allen et al. 1997; Medici et al. 2016). Pumping tests $(n=33 ; T=0.46-$ $8.82 \mathrm{~m}^{2} /$ day) were also undertaken at greater depth (200400 m BGL; Streetly et al. 2000) in the fluvial St Bees Sandstone aquifer. In this work hydro-geophysical data from the St Bees Sandstone fluvial aquifer at up to 1,100 m BGL will also be considered, in order to achieve a better understanding of the mechanisms that control hydraulic conductivity with depth.

\section{Methods}

The St Bees Sandstone aquifer from outcrop up to $1,100 \mathrm{~m}$ BGL has been investigated in this work at both core-plug and well-test scale. Plug-scale petrophysical analysis (petrographic microscope, scanning electron microscope with energy dispersive spectrometry (EDX), nuclear magnetic resonance (NMR), porosity and permeability tests), packer tests, pumping tests, and televiewer, static (caliper, gamma-ray, neutron porosity) and fluid (temperature, conductivity and flow velocity) logs were analyzed, the aim being to characterize the properties of this fluvial aquifer type at a range of scales (see Fig. 2).

Hydraulic conductivity has been investigated in this work by testing core plugs and analyzing single-borehole pumping and packer tests. The core plug (4-6 cm in length) represents the smallest scale of investigation for permeability. Singleborehole pumping and packer tests investigate the aquifer at a similar scale ( 50-200 m; Fig. 2; Nirex 1992b, 1993a). Results from these tests were then compared to multiborehole packer tests undertaken by Streetly et al. (2000), which represent a larger investigation scale $(\sim 50-1,000 \mathrm{~m}$; Fig. 2).

\section{Core-plug scale petro-hydraulic characterization}

Twenty-two core plugs from the St Bees Sandstone Formation of the eastern Irish Sea Basin were obtained from outcrops at South Head cliff, and Sandwith and Hutbank quarries (Figs. 1, 3, 4; Table 1). These plugs were characterized for porosity, permeability, and NMR response, and by using a petrographic microscope and SEM analyses in different sedimentary units. Core plugs of
Fig. 2 Summary scheme of the multi-scale dataset used to characterize the West Cumbrian St Bees Sandstone aquifer (modified from Paradis et al. 2014)

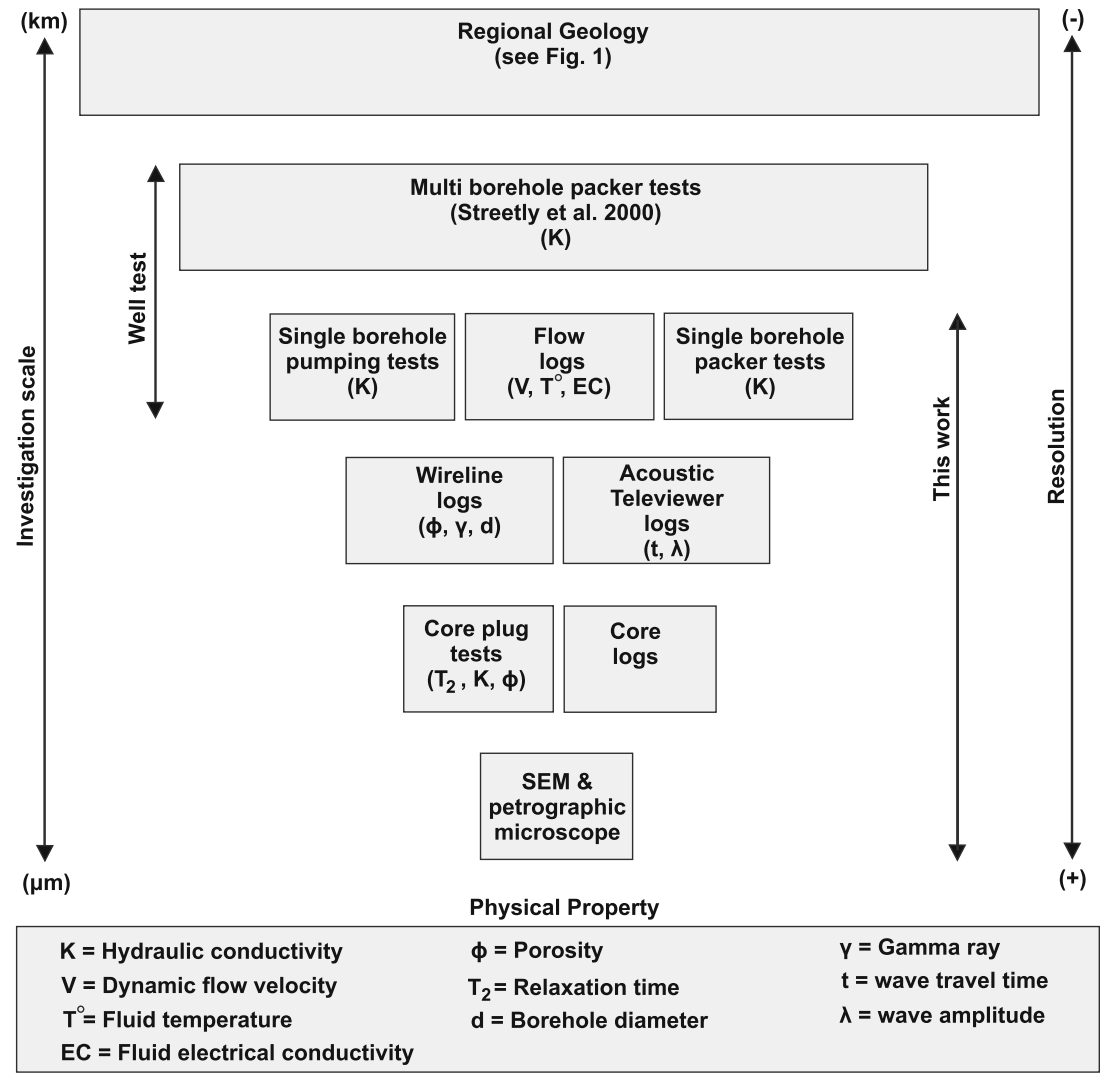




\section{Sedimentary Heterogeneities}
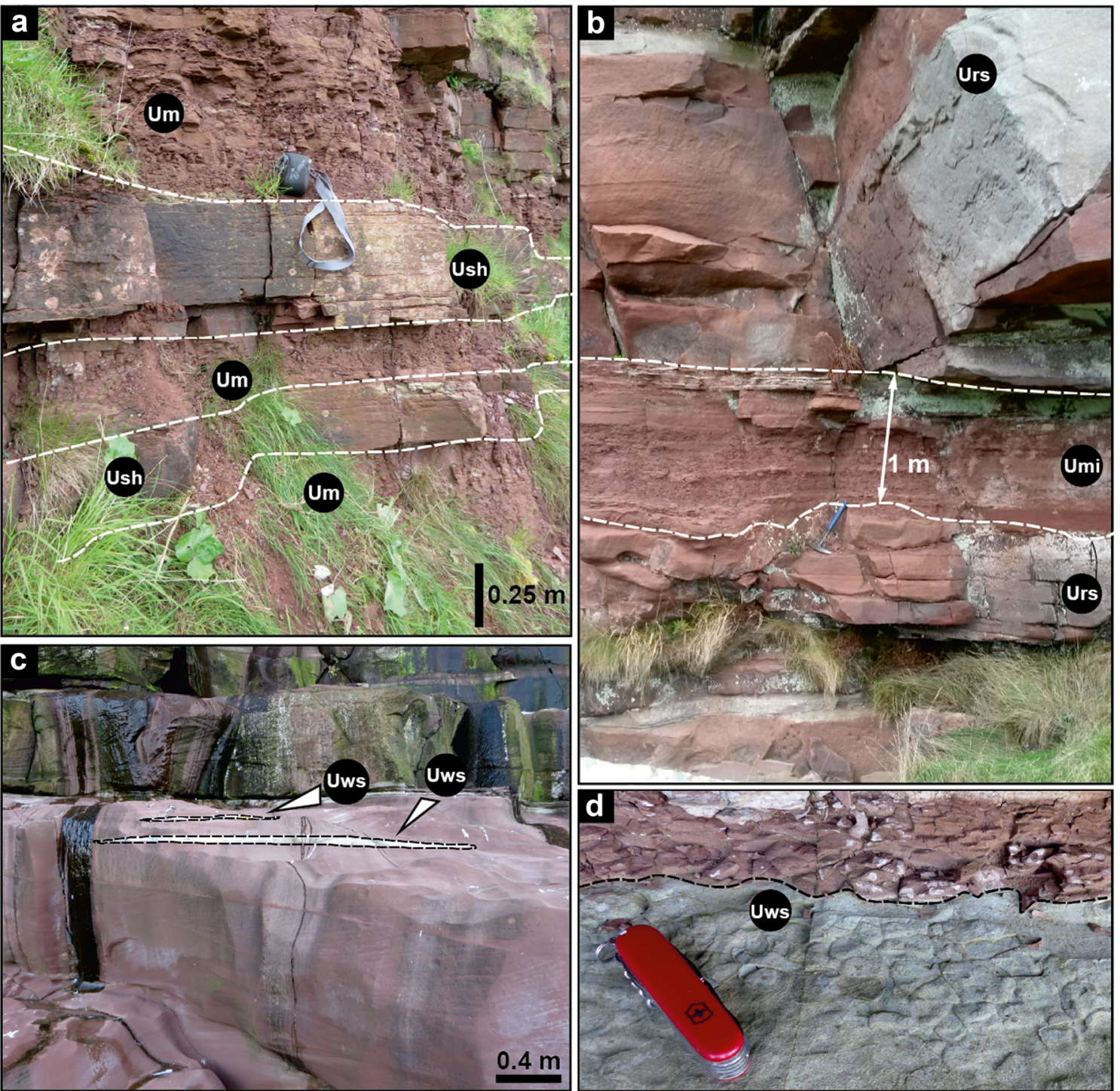

Fig. 3 St Bees Sandstone Formation in outcrop, sedimentary heterogeneities. a Lower North Head Member at Saltom Bay showing the basal alternation of sheet-like sandstone (Ush) and mudstone beds (Um), b Mudstone (Umi) interlayered in the red-channelized sandstone

(Urs), c White-channel sandstone (Uws) layers which laterally extend $\sim 2.5 \mathrm{~m}$, d Plan view of desiccation cracks in the white-channel sandstone (Uws)

cylindrical shape (diameter $=18 \mathrm{~mm}$; length $=60 \mathrm{~mm}$ ) were first tested for permeability. Next, porosity was calculated using the liquid saturation method based on Archimedes' principle and then NMR analysis was realized. Water of composition representative of the Sherwood Sandstone aquifer groundwater was synthesized in the laboratory $(\mathrm{pH}=7.7$; Salinity $=67 \mu \mathrm{S} / \mathrm{m}$; Lewin et al. 1994) and was used to clean plugs prior to porosity and permeability measurements.

A constant flow-rate permeameter equipped with a pressure transducer was used to measure saturated hydraulic conductivity on cylindrical plugs cored in orientations both parallel and perpendicular to the bedding (Table 1). Differential pressures used for permeability tests ranged from 0.1 up to $30 \mathrm{kPa}$. NMR tests provided both total porosity and $T_{2}$ (transverse relaxation time) distribution (Hossain et al. 2011; Megawati et al. 2012). NMR measurements were made using a Resonance Instruments MARAN 2 spectrometer at ambient pressure and $34{ }^{\circ} \mathrm{C}$ at a proton resonance frequency of $2.2 \mathrm{MHz}$. The $T_{2}$ relaxation curves were measured by using a repetition time of $10 \mathrm{~s}$, the number of echoes set to 8000 , inter-echo spacing of $200 \mu$ s, the number of scans set to 100 and receiver gain set to 65 . Finally, polished blocks and petrographic thin sections were prepared from core plugs which were previously tested for NMR, porosity and permeability analyses. The petrographic microscope was coupled with the X-ray energy histograms from the energy dispersive spectrometry (EDX) of the scanning 

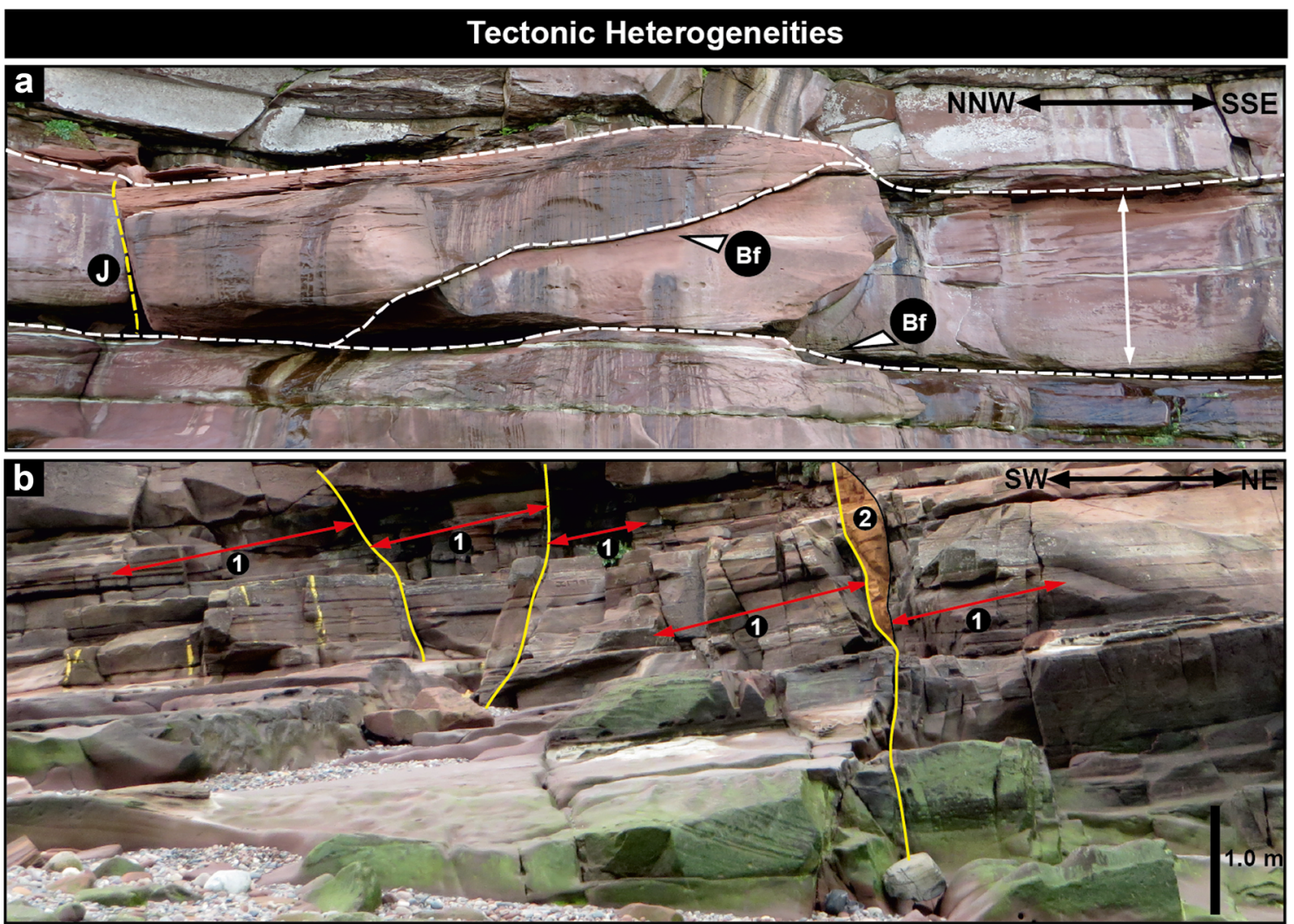

Fig. 4 St Bees Sandstone Formation in outcrop, tectonic heterogeneities. a Outcrop expression of the amalgamated channels of the South Head Member showing bedding plane fractures $(\mathrm{Bf})$ and vertical stratabound joints $(\mathrm{J})$ white bar of $1.5 \mathrm{~m}$ for scale, $\mathbf{b}$ Normal faults deforming the amalgamated channels at South Head dominated by damage zones with open fractures (1) and noncontinuous fault core (2) electron microscope (SEM) to detect mineralogical species. Additionally, petrographic microscope and SEM images were studied to constrain core-plug scale sedimentary heterogeneities (see Fig. 2).

Table 1 Summary of petrophysical values (porosity, permeability) of 22 plugs from the St Bees Sandstone Formation outcrop, this study. NA not applicable

\begin{tabular}{|c|c|c|c|c|c|c|}
\hline Sample (plug code) & Location (see Fig. 1) & Sedimentary unit & $\begin{array}{l}\text { Bulk porosity, } \\
\text { Archimedes (\%) }\end{array}$ & NMR porosity (\%) & $K_{\mathrm{h}} ; K_{\mathrm{v}}(\mathrm{m} /$ day $)$ & $\begin{array}{l}\text { Anisotropy, } \\
K_{\mathrm{h}} / K_{\mathrm{v}}\end{array}$ \\
\hline $1(1 \mathrm{~h} ; 1 \mathrm{v})$ & $\begin{array}{l}\text { South Head } \\
\text { Cliff }\end{array}$ & \multirow{6}{*}{$\begin{array}{l}\text { Red-channel } \\
\text { Sandstone } \\
\text { (Urs) }\end{array}$} & 22.9 & 21.0 & $0.73 ; 0.29$ & 2.5 \\
\hline $2(2 \mathrm{~h} ; 2 \mathrm{v})$ & $\begin{array}{l}\text { South Head } \\
\text { Cliff }\end{array}$ & & 20.6 & 18.8 & $0.51 ; 0.15$ & 3.5 \\
\hline $3(3 \mathrm{~h} ; 3 \mathrm{v})$ & $\begin{array}{l}\text { South Head } \\
\text { Cliff }\end{array}$ & & 21.5 & 20.1 & $0.44 ; 0.29$ & 1.5 \\
\hline $4(4 \mathrm{~h} ; 4 \mathrm{v})$ & $\begin{array}{l}\text { South Head } \\
\text { Cliff }\end{array}$ & & 21.7 & 20.7 & $3.65 ; 0.43$ & 8.5 \\
\hline $5(5 \mathrm{~h} ; 5 \mathrm{v})$ & $\begin{array}{l}\text { South Head } \\
\text { Cliff }\end{array}$ & & 20.4 & 18.4 & $2.92 ; 0.37$ & 8.0 \\
\hline $6(6 \mathrm{~h} ; 6 \mathrm{v})$ & $\begin{array}{l}\text { Sandwith } \\
\text { Quarry }\end{array}$ & & 19.1 & 17.7 & $0.36 ; 0.18$ & 2.0 \\
\hline $7(7 \mathrm{v})$ & $\begin{array}{l}\text { South Head } \\
\text { Cliff }\end{array}$ & $\begin{array}{l}\text { White-channel } \\
\text { Sandstone }\end{array}$ & 9.7 & 8.4 & $\mathrm{NA} ; 3.3 \times 10^{-4}$ & NA \\
\hline $8(8 v)$ & $\begin{array}{l}\text { South Head } \\
\text { Cliff }\end{array}$ & (Uws) & 11.3 & 9.3 & $\mathrm{NA} ; 2.63 \times 10^{-3}$ & NA \\
\hline $9(9 \mathrm{~h} ; 9 \mathrm{v})$ & Hutbank Quarry & Sheet-like & 15.9 & 13.1 & $0.22 ; 7.30 \times 10^{-3}$ & 30.0 \\
\hline $10(10 \mathrm{~h} ; 10 \mathrm{v})$ & Hutbank Quarry & Sandstone & 17.6 & 15.1 & $4.38 \times 10^{-2} ; 3.65 \times 10^{-3}$ & 12.0 \\
\hline $11(11 \mathrm{~h} ; 11 \mathrm{v})$ & Hutbank Quarry & (Ush) & 17.1 & 17.1 & $6.81 \times 10^{-3} ; 3.55 \times 10^{-4}$ & 19.2 \\
\hline $12(12 \mathrm{~h} ; 12 \mathrm{v})$ & Hutbank Quarry & & 17.3 & 17.3 & $1.07 \times 10^{-2} ; 3.70 \times 10^{-4}$ & 29.0 \\
\hline
\end{tabular}


Laboratory tests undertaken in this work were also compared with porosity and permeability measurements from core plugs of the St Bees Sandstone aquifer which were extracted from the British Geological Survey (BGS)'s archives (Tables 2 and 3; see references therein). Then, a sedimentary unit was assigned to each core plug, i.e. availability of geological core logs from the Sellafield repository investigation (BGS's archives).

Core plugs from the outcrop were tested using simulated groundwater (electrical conductivity, $67 \mu \mathrm{S} / \mathrm{m}$ ); however, core plugs from the previous investigations were tested using air; then the Klinkenberg correction was applied to allow integration (Allen et al. 1997; Nirex 1992a, c, 1993b, c).

\section{Well-test scale hydro-geophysical characterization}

Historical single-borehole pumping and packer tests data from the studied wells were reanalyzed using the ESI AquiferWin32 V.5 software package as part of this study, to obtain reliable transmissivity values from single-borehole pumping tests from both the shallow aquifer $(<150 \mathrm{~m} \mathrm{BGL}$; Bridge End Trial, Rottington Trial, West Cumbria ABH 1; all UK Environment Agency groundwater monitoring wells) and the deep aquifer beneath the Calder and Ormskirk Sandstone formations (150-1,100 m BGL, conducted in deep Sellafield boreholes $\mathrm{BH} 2$ and $\mathrm{BH} 3)$. Transmissivity values were converted into mean well-test scale hydraulic conductivity by dividing by the screen length; this assumes sub-horizontal flow. This assumption is reasonable given the layered nature of the aquifer $\left(K_{\mathrm{h}}>K_{\mathrm{v}}\right.$ at the well-test scale, Streetly et al. 2000). Step pumping tests in West Cumbria ABH1 and Bridge End Trial wells were analyzed using the Eden and Hazel (1973) step-test analysis methodology, which determines transmissivity from single-borehole tests in confined aquifers. Step test analysis has been preferred to analysis of the available constant flow rate tests in Bridge End Trial and West Cumbria ABH 1, since the former takes into account wellloss correction (Clark 1977; Eden and Hazel 1973; Houben 2015; Mathias et al. 2008; Mathias and Lindsay 2010). However, aquifer transmissivities have also been computed using the Theis (1935) methodology where data relating to recovery phase (or pressure build-up) associated with constant flow-rate tests are available, as is the case for the Rottington Trial and in the deep Sellafield borehole well tests- $-\mathrm{BH} 2$ 1,
BH2 s, BH3 1, BH3 s (the letters 1 and s stand for the long and short interval tests conducted in these wells, see Table 4 for details).

\section{Borehole geophysical logs}

Acoustic televiewer logs (Advanced Logic Technology QL40 $\mathrm{mk} 5$ ), caliper and conductivity and temperature fluid logs (pumped conditions, sampling fluid each centimeter) have been run in the shallow St Bees Sandstone aquifer by European Geophysical Services Limited (Shrewsbury, UK) in the Rottington Trial borehole. Dynamic flow velocity was logged in the Rottington Trial borehole while pumping water from $\sim 10 \mathrm{~m}$ below the water table at $150 \mathrm{~L} / \mathrm{min}$, using an impeller flow-meter (Geovista mk2). Fluid flow velocity was analyzed using a quantitative approach that assumes (1) quasi-steady state flow under pumped conditions, and (2) negligible ambient flow; hence, this approach only requires data from the pumped flow logs (Table 5; Molz et al. 1989; Fienen et al. 2004; Parker et al. 2010). This methodology determines the transmissivity $\left(T_{i}\right)$ for each layer $(i)$, simply from the proportion of total inflow to the well entering from that layer under pumped conditions, and the overall well pumping test transmissivity $(T)$. Core logs, pumping tests, and caliper, gamma-ray, neutron porosity, fluid conductivity and temperature logs (pumped conditions, sampling fluid every $0.15 \mathrm{~m}$ ) in the deep confined St Bees Sandstone intercepted by Sellafield $\mathrm{BH} 2$ and 3 were provided by BGS; these data were originally acquired by Schlumberger during the 1990s.

Dynamic flow velocity, fluid conductivity and temperature were analyzed under pumped conditions. These techniques investigate the rock at larger scale with respect to acoustic televiewer and wireline $\operatorname{logs}$ which penetrate $<0.5 \mathrm{~m}$ (Bridge and Tye 2000). In fact, the investigation scale of flow velocity, fluid conductivity and temperature logs under pumped conditions are similar to that of single-borehole pumping and packer $(\sim 50-200 \mathrm{~m})$ tests, i.e. the scale of the perturbation in the borehole is due to the stressing of the water table (Fig. 2; Day-Lewis et al. 2011; Paillet 1998, 2001).

\section{Upscaling hydraulic conductivity}

Transmissivity values from short-screen well tests $(<25 \mathrm{~m}$; $\mathrm{BH} 2 \mathrm{~s}, \mathrm{BH} 3 \mathrm{~s}$ ) in the deep St Bees Sandstone aquifer were

Table 2 Summary of porosity and core-plug-scale hydraulic conductivity parallel $\left(K_{h}\right)$ and perpendicular $\left(K_{v}\right)$ to the sedimentary laminations in the St Bees Sandstone aquifer from the BGS archives (borehole core plugs)

\begin{tabular}{lcllll}
\hline Depth interval (m BGL) & Population & Reference & Porosity range $(\%)$ & $K_{\mathrm{h}}(\mathrm{m} /$ day $)$ & $K_{\mathrm{v}}(\mathrm{m} /$ day) \\
\hline $12-92$ & 59 & Allen et al. 1997 & $4.8-25.9$ & $1.21-9.14 \times 10^{-6}$ & $0.26-4.16 \times 10^{-6}$ \\
$70-1,070$ & 161 & Nirex 1992a, c, 1993b, c & $2.1-23.0$ & $0.77-4.16 \times 10^{-6}$ & $0.71-2.49 \times 10^{-6}$ \\
\hline
\end{tabular}


Table 3 Summary of geometric means (GM) of hydraulic conductivity parallel $\left(K_{h}\right)$ and perpendicular $\left(K_{v}\right)$ to the bedding and resulting permeability anisotropy $\left(K_{h} / K_{v}\right)$ from core plugs in the St Bees Sandstone aquifer (data from Allen et al. 1997, Nirex 1992a, c, 1993b, c)

\begin{tabular}{|c|c|c|c|c|c|c|}
\hline Petrophysical groups & Population & $K_{\mathrm{h}}(\mathrm{m} /$ day $)$ & GM $K_{\mathrm{h}}(\mathrm{m} /$ day $)$ & $K_{\mathrm{v}}(\mathrm{m} /$ day $)$ & GM $K_{\mathrm{v}}(\mathrm{m} /$ day $)$ & $\begin{array}{l}\text { GM anisotropy, } \\
K_{\mathrm{h}} / K_{\mathrm{v}}\end{array}$ \\
\hline $\begin{array}{l}\text { Red-channel } \\
\text { sandstone (Urs) }\end{array}$ & 150 & $4.99 \times 10^{-5}-1.21$ & $1.57 \times 10^{-2}$ & $1.66 \times 10^{-5}-0.72$ & $5.08 \times 10^{-3}$ & 3.1 \\
\hline $\begin{array}{l}\text { Mudstone interbedded with } \\
\text { channel sandstone (Umi) }\end{array}$ & 27 & $4.15 \times 10^{-6}-1.18 \times 10^{-2}$ & $2.14 \times 10^{-4}$ & $2.49 \times 10^{-6}-4.15 \times 10^{-2}$ & $5.50 \times 10^{-5}$ & 5.0 \\
\hline Sandstone floodplain (Ush) & 27 & $4.15 \times 10^{-5}-1.66 \times 10^{-2}$ & $5.01 \times 10^{-3}$ & $1.16 \times 10^{-5}-1.10 \times 10^{-1}$ & $1.21 \times 10^{-3}$ & 4.1 \\
\hline Mudstone floodplain (Um) & 16 & $7.50 \times 10^{-6}-4.44 \times 10^{-2}$ & $9.05 \times 10^{-4}$ & $4.49 \times 10^{-6}-4.32 \times 10^{-3}$ & $1.54 \times 10^{-4}$ & 5.9 \\
\hline
\end{tabular}

compared with upscaled values derived from hydraulic conductivities from core plugs from the same interval. The horizontal hydraulic conductivity from sandstone plugs was upscaled using the geometric mean of the plug values and the screen length to give screened interval transmissivity. Flow in this upscaling approach is assumed bed-parallel and sub-horizontal due to the shallow dip and layered nature of the aquifer (the dip of the beds is 17 and $8^{\circ}$ for $\mathrm{BH} 2 \mathrm{~b}$ and $\mathrm{BH} 3 \mathrm{~b}$, respectively). Geometric and arithmetic means are typically used for upscaling of horizontal hydraulic conductivity in heterogeneous sandstone aquifers and hydrocarbon reservoirs (Chen et al. 2003; Jackson et al. 2003). The geometric mean was used in this work as it well represents horizontal flow with log-normal distributed populations of plug-scale permeability values (Maliva and Missimer 2010; Zheng et al. 2000).

\section{Core-plug scale properties of fluvial deposits}

\section{Palaeoenvironmental significance of core plugs}

Twenty-two core plugs from outcropping St Bees Sandstone Formation (Fig. 1) were tested for porosity, permeability and $T_{2}$ distribution. These same plugs have then been the object of SEM and petrographic microscope analysis aiming to define their micro-heterogeneities and mineralogical composition. The 22 core plugs that have been tested cover a range of lithologies with different palaeoenvironmental significance. Where possible, plugs have been cored along directions both parallel and perpendicular to bedding (Table 1). Outcrop exposures at the Saltom Bay and South Head cliffs (Figs. 3 and 4) allow to link the tested plugs to architectural elements and lithofacies related to specific palaeoenvironments (e.g., floodplain, channel-fills). Twelve plugs coded 1-6 (including six cored horizontally and six cored vertically) have been grouped in a single sedimentary unit which has been named redchannel sandstone (Urs; Figs. 3a-d and $4 \mathrm{a}-\mathrm{b}$ ). This sedimentary unit is red in color and is characterized by medium grain size and medium-to-well-sorted sandstone (Urs). These 12 plugs characterize both cross-bedded (planar and sigmoidal) and horizontally laminated sandstone representing the preserved deposits of sandy barforms (Table 1). Plugs coded 7 and 8 are representative of white in-channel drapes (Uws) that overlie bedform deposits during episodes of low-flow stage. Additionally, this white-channel sandstone (Uws) contains desiccation cracks which indicate periods of subaerial exposure and drying (Uws, Fig. 3c-d). The occurrence of welldeveloped thin laminations and desiccation cracks created a strong mechanical anisotropy and samples disintegrated during coring parallel to laminations. Eight plugs coded 9-12 (including four cored horizontally and four cored vertically) were tested from sheet-like sandstone interpreted to have been deposited by nonconfined flood events in a floodplain environment (Ush, Fig. 3a; Table 1). All 22 plugs analyzed in this work have been compared with previous porosity and plugscale permeability tests that have been conducted on the $\mathrm{St}$ Bees Sandstone aquifer as part of the planning for the Sellafield nuclear waste repository (Allen et al. 1997; Nirex 1992a, c, 1993b, c). This integration allowed for enlargement of the database used for statistical analyses of porositypermeability data to include that relating to floodplain mudstone (fluvial deposits due to nonconfined flood events) origin (Fig. 3a, Um), as well as for interbedded fluvial channel and mudstone elements (Fig. 3b, Umi).

\section{Results: SEM and optical microscope analysis}

SEM and optical microscope images (Figs. 5a-f, 6a-f and 7ac) realized on three different sandstone units show how the sheet-like (Ush) and the white-channel (Uws) sandstones are characterized by a fine-grained sand, whereas the red-channel sandstone (Urs) is medium-grained sandstone. SEM and optical microscope (Figs. 5, 6 and 7a-c) analyses show how all the three analyzed sedimentary units (Urs, Ush, Uws) are characterized by quartzo-feldspathic sandstone (quartz 50-60\%; feldspar 10-15\%; other grains 25-40\%). Quartz represents the main mineralogical component, followed by K-feldspar, plagioclase, biotite, muscovite, illite and chlorite. Other minerals identified include hematite and titanite. 
Energy-dispersive X-ray spectroscopy (EDX) analysis realized on red-channel (Urs) and sheet-like sandstone (Ush) and white-channel sandstone (Uws) reveal a systematic difference of cement composition between the two reddish sedimentary units (Urs, Ush) and the white sandstone (Uws). The cement (type-1) of the white-silty drape sandstone (Uws) is quartzo-feldspathic (96-100 wt \%) and characterized by paucity or absence of hematite $(0-2 \mathrm{wt} \%)$ and calcite $(0$ $2 \mathrm{wt} \%)$. Although quartz and feldspars (80-95 wt\%) also represent the main cement components in the sheet-like sandstone (Ush) and the red-channel sandstone (Urs), these units are typically characterized by a cement (type-2) with a significant hematite component $(5-20 \mathrm{wt} \%)$ and the paucity or absence of calcite $(0-1.5 \mathrm{wt} \%)$.

Optical microscope analyses show that samples of sheetlike (Ush) and white-channel (Uws) sandstones are characterized by a repetitive alternation of laminae of different grain and pore sizes which are 200 up to $500 \mu \mathrm{m}$ thick (Fig. 6c-f). Coarser-grained laminations are characterized by larger pores (Fig. 6d). Thin sections in the white-channel sandstone (Uws) show absence of pores with diameter $>150 \mu \mathrm{m}$ since these pores are partially or completely filled by cement (Figs. 5c-d; 7a). By contrast, relatively larger pores $(>150 \mu \mathrm{m})$ are present in the sheet-like and red-channel sandstones and their dimension increases moving from the sheet-like (Ush) to the redchannelized (Urs) sandstone (Fig. 7b-c). Macro-pores show maximum diameter up to 180 and $250 \mu \mathrm{m}$ in sheet-sandstone and red-channel sandstone, respectively (Figs. $5 \mathrm{f}$ and $7 \mathrm{~b}-\mathrm{c}$ ). However, preferential orientation of platy minerals (biotite, muscovite, illite and chlorite) parallel to bedding is systematically detectable at the microscopic scale in all the three sedimentary units (Figs. 5a-f; 6c-e and 7a-b; Urs, Uws, Ush). This is because quartz grains of ellipsoid shape and mud-clasts are also oriented parallel to the bedding laminations in all the studied lithofacies.

Pores show a typical triangular shape in the white-channel sandstone (Uws). However, elliptical sections are the most common pore outline in the sheet-like sandstone (Ush), although this lithology also commonly shows triangular shape-type pores. The red-channel (Urs) sandstone is characterized by ellipsoid and coalescent pores of irregular shape. Thus, the shape of pores changes from triangular, to ellipsoid, to irregular with increasing pore dimension and connectivity (Fig. 7a-c).

\section{Results: petrophysical analysis}

Petrophysical measurements on 22 core plugs from the $\mathrm{St}$ Bees Sandstone Formation include measurements of hydraulic conductivity, porosity and $T_{2}$ distribution. Total porosity of samples has been calculated both with the Archimedes and NMR methodologies, which gave values of 9.7-22.9\% and 8.4-21.0\%, respectively (Table 1). NMR porosity thus yields 
Table 5 Parameters computed from the flow log analysis for the Rottington Trial borehole (shallow St Bees Sandstone aquifer) by applying the Molz et al. (1989) approach to the pumping test-derived transmissivity of $77 \mathrm{~m}^{2} /$ day, to find layer K

\begin{tabular}{lllll}
\hline $\begin{array}{l}\text { Code } \\
\text { zone }\end{array}$ & $\begin{array}{l}\text { Bottom depth m (BGL; } \\
\text { ASL) }\end{array}$ & $\begin{array}{l}\text { Layer thickness } \\
(\mathrm{m})\end{array}$ & $\begin{array}{l}\text { Delta } \\
\text { V/Vmax }\end{array}$ & $\begin{array}{l}\text { Hydraulic conductivity } \\
(\mathrm{m} / \text { day })\end{array}$ \\
\hline L7 & $40 ; 13.0$ & 8.7 & 0.14 & 1.2 \\
L6 & $66.9 ;-13.9$ & 17.3 & 0.30 & 1.3 \\
L5 & $77 ;-24.0$ & 10.1 & 0.00 & $<0.1$ \\
L4 & $91.5 ;-38.5$ & 14.5 & 0.23 & 1.2 \\
L3 & $103 ;-50.0$ & 11.5 & 0.03 & 0.2 \\
L2 & $114.7 ;-61.7$ & 11.7 & 0.39 & 2.6 \\
L1 & $120 ;-67.0$ & 5.3 & 0.05 & 0.8 \\
\hline
\end{tabular}

values from 'equal to' to $18 \%$ lower than Archimedes measurements. Archimedes porosity provides more reliable values than NMR porosity for the St Bees Sandstone Formation due to presence of mineral species with high magnetic susceptibilities. The presence of paramagnetic ions in iron-bearing minerals (e.g., hematite) represent an important factor influencing $T_{2}$ measurements. Paramagnetic ions increase the rate of relaxation of the hydrogen proton, consequently reducing $T_{2}$ values (Dodge et al. 1995). Additionally, chlorite, muscovite and biotite have large surface area and elevated magnetic susceptibilities, leading to large magnetic field gradients and low $T_{2}$ values (Morriss et al. 1997; Hossain et al. 2011). Archimedes porosity (Table 1) increases moving from the white-channel $(9.7-11.3 \%)$ to the sheet-like sandstone (15.9-17.6\%) up to the red-channel sandstone (19.1$22.9 \%$ ). Wireline logs which were previously realized in the West Cumbrian St Bees Sandstone (see Fig. 1b) confirm the contrast in porosity between the red-channel sandstone (Urs) that makes up the bulk of the rock and the thin white-silty drape sandstone (Uws) since lower neutron porosity values typically characterize the latter lithotype.

Hydraulic conductivity values measured on rock samples of the St Bees Sandstone Formation show values that range over five orders of magnitude $\left(K_{\mathrm{h}}=6.81 \times 10^{-3}-3.65 \times 10^{0} \mathrm{~m} /\right.$ day; $K_{\mathrm{v}}=3.33 \times 10^{-4}-4.30 \times 10^{-1} \mathrm{~m} /$ day) and anisotropy values $\left(K_{\mathrm{h}} / K_{\mathrm{v}}\right)$ that range from 1.5 to 30.0 (Table 1$)$. Note, $K_{\mathrm{h}}$ values are not available for the white-channel sandstones since samples disintegrated (see Table 1). Optical microscope and SEM (Figs. 5 and 6) observations reveal how this anisotropy is related to (1) presence of finer-grained laminations characterized by small and low-connectivity pores and (2) preferential orientations of mud-clasts, platy (muscovite, biotite, chlorite, illite) and ellipsoid mineral grains (quartz). The microscope optical images illustrate the origin of the relatively higher anisotropy values $\left(K_{\mathrm{h}} / K_{\mathrm{v}}=12.0-30.0\right)$ for sheet-like sandstone compared to the red-channelized sandstone $\left(K_{\mathrm{h}} /\right.$ $\left.K_{\mathrm{v}}=1.5-8.5\right)$. This contrast arises because the sheet-like sandstone facies (Ush) is characterized by laminations with different grain and pore sizes and abundance of mica and clay minerals, whereas the red-channelized sandstone facies (Urs) is not, and is therefore more isotropic. Notably, well- developed laminations also occur in the white silty sandstone which also appear strongly anisotropic at the petrographic microscope (Fig. 6c-d). In fact, these laminations, together with desiccation cracks, form the strong mechanical anisotropy that prevented coring parallel to bedding.

$T_{2}$ distributions (Fig. 7) for the white-channel (Uws), the sheet-like (Ush) and the red-channel (Urs) sandstone are essentially unimodal, i.e. single intensity peaks at $\sim 2, \sim 16$ and $\sim 100 \mathrm{~ms}$, respectively. Also, the modal $T_{2}$ values show positive correlation with the core-plug scale hydraulic conductivity (Fig. 7). The hydraulic conductivity ranges for the three sedimentary units are as follows: white-drape sandstone $\left(K_{\mathrm{v}}=3.33 \times 10^{-4}\right.$ $2.63 \times 10^{-3} \mathrm{~m} /$ day $)$; sheet-like sandstone $\left(K_{\mathrm{v}}=3.55 \times 10^{-4}\right.$ $7.30 \times 10^{-3} ; K_{\mathrm{h}}=6.81 \times 10^{-3}-0.22 \mathrm{~m} /$ day $)$; red-channel sandstone $\left(K_{\mathrm{v}}=0.15-0.43 ; K_{\mathrm{h}}=0.36-3.65 \mathrm{~m} /\right.$ day $)$. Results also show the same rank order of their peak $T_{2}$ values: $\sim 2, \sim 16$, and $\sim 100 \mathrm{~ms}$, respectively. Furthermore, optical images show how these petrophysical groups are characterized by evident different pore sizes which increase moving from white drape sandstone (Uws), to sheet-like sandstone (Ush), to the redchannelized sandstone (Urs; Fig. 7a-c). Permeability, pore-size and $T_{2}$ distribution in the St Bees Sandstone are therefore closely related. Core plugs show positive correlation between $T_{2}$ values and hydraulic conductivity along both the horizontal and the vertical direction (Fig. S1 of the electronic supplementary material (ESM); Table 1). Notably, the correlation between $T_{2}$ modal values and hydraulic conductivity is stronger along the horizontal direction (red symbols in Fig. S1 of the ESM), probably because the modal $T_{2}$ values are more markedly influenced by the larger pores, whereas the smaller pores control the minimum hydraulic conductivity $\left(K_{\mathrm{v}}\right)$.

\section{Archive petrophysical values}

Plug-scale hydraulic conductivities measured in this work on outcrops of the St Bees Sandstone Formation in the Saltom Bay to South Head area are here compared with measurements from plugs cored from both shallow boreholes (Robertgate Bridge, Low Priory Scales) in the Egremont area, and deep cores obtained from the Sellafield data archive (see boxed area labeled 'proposed Sellafield repository' in Fig. 1b for locations). Porosity 

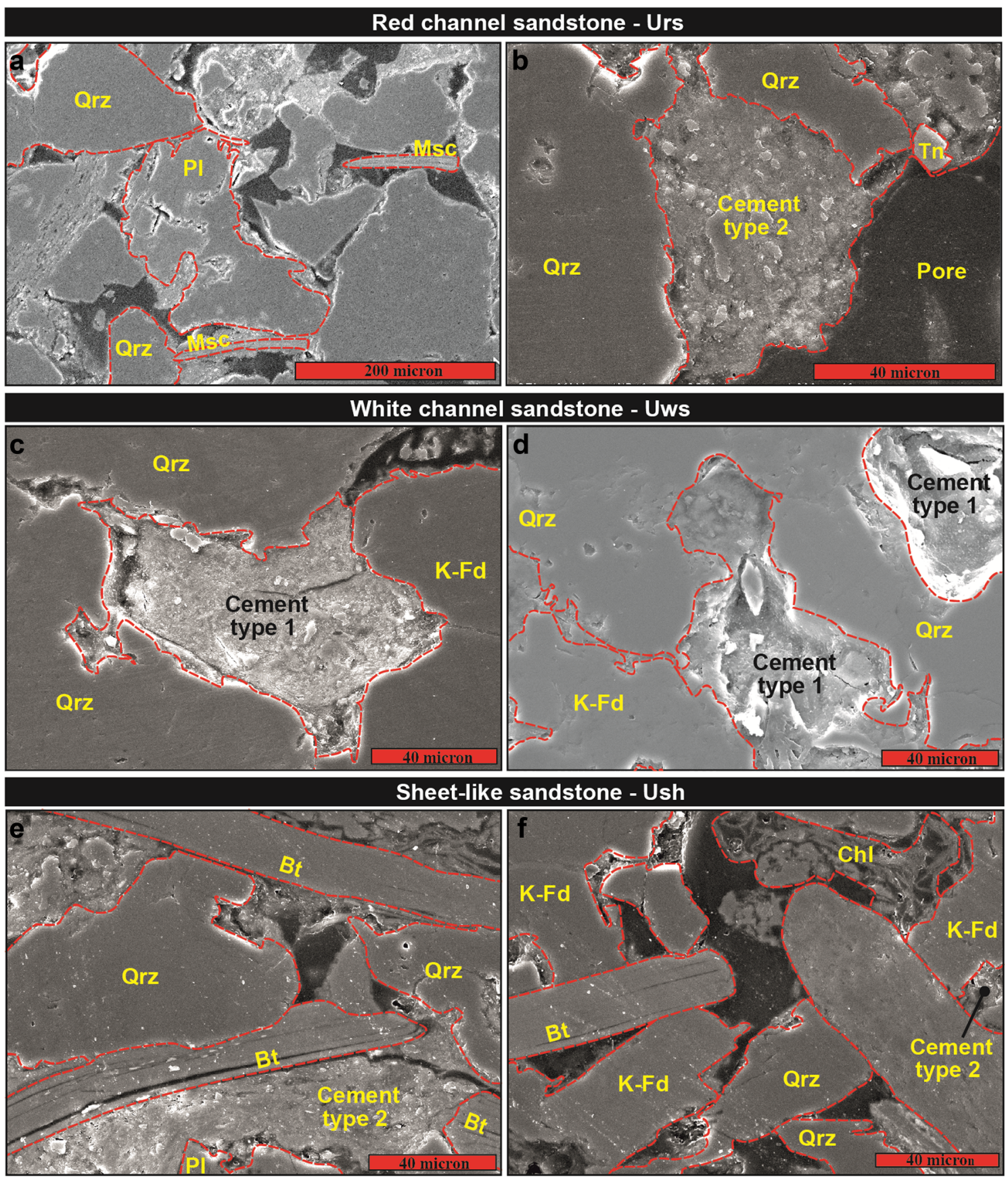

Fig. 5 SEM images from the St Bees Sandstone Formation. a Quartz (Qrz), plagioclase $(\mathrm{Pl})$ and muscovite $(\mathrm{Msc})$ grains elongated parallel to the bedding in red-channel sandstone, b Quartz (Qrz) and titanite (Tn) grains and a large pore partially filled by cement type 2 in red-channel sandstone, c Quartz (Qrz) and K-feldspar (K-Fd) and cement type 1 which fills pores in white-channel sandstone, d Quartz (Qrz), Kfeldspar (K-Fd) grains and cement type 1 completely filling pores in

and hydraulic conductivity values from outcrop samples tested here and from the previous shallow and deep aquifer investigations are summarized in Fig. 8 and Tables 1, 2 and 3.

The porosity-permeability characteristics of four distinct sedimentary units are illustrated in Fig. 8a-c: red-channel sandstone

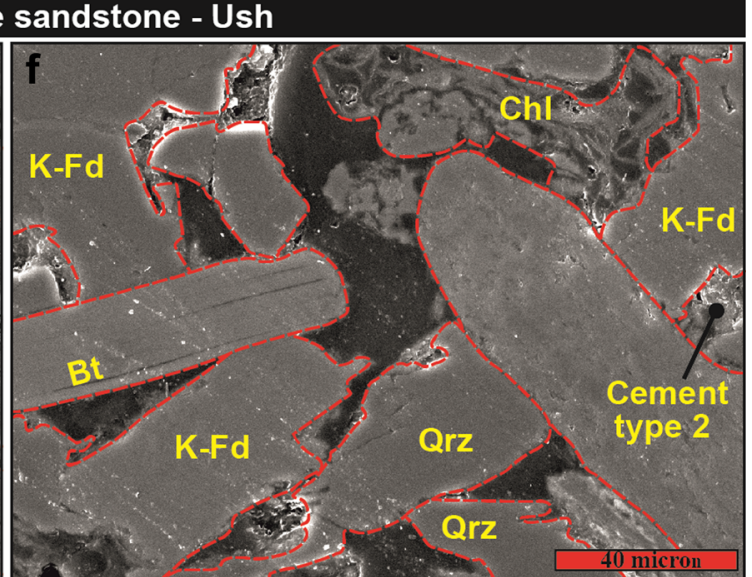

white-channel sandstone, e Floodplain sheet-like sandstone: biotite (Bt) grains are elongated parallel to the sedimentary laminations, quartz (Qrz), plagioclase (Pl) and cement type 2 were confirmed by EDX analysis, $\mathbf{f}$ Floodplain sheet-like sandstone: biotite $(\mathrm{Bt})$ and chlorite $(\mathrm{Chl})$ grains are elongated parallel to the sedimentary laminations, quartz (Qrz), Kfeldspar (K-Fd) and cement type 2 were also detected by EDX analysis

(Urs), floodplain mudstone (Um), floodplain sandstone (Ush) and mudstone, and mudstone interlayered in channels $(\mathrm{Um} /$ Umi). Note that mudstone (Um), which characterizes the floodplain deposits, and mudstone that occurs interbedded with channel deposits (Umi) were not sampled from outcrop. Archive 

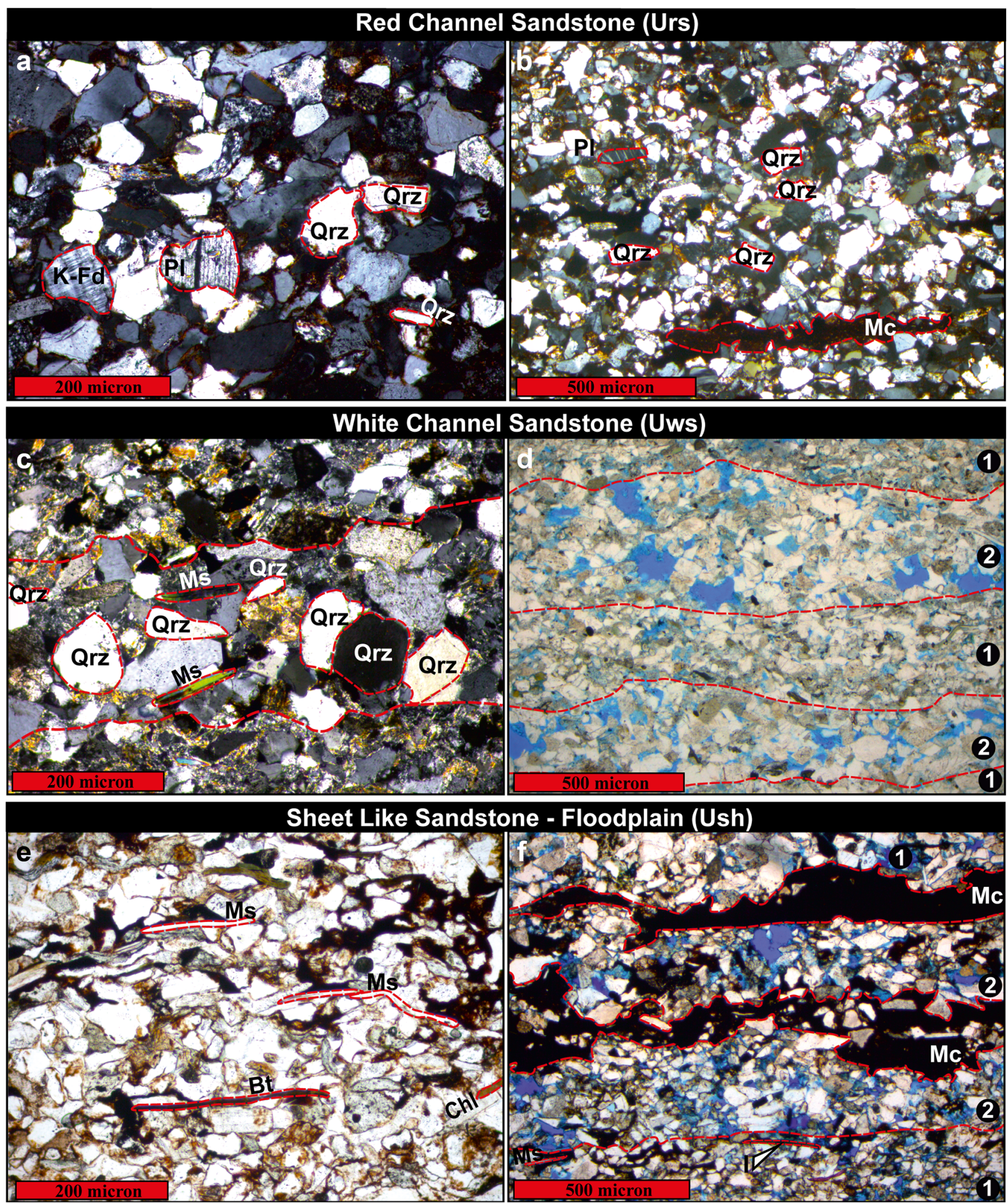

Fig. 6 Petrographic optical microscope images from the St Bees Sandstone Formation ( $\mathbf{a}-\mathbf{c}$, cross polarized light; $\mathbf{d}-\mathbf{f}$ plane polarized light). a Quartz (Qrz), plagioclase (Pl) and K-feldspar (K-Fd) grains in a medium-grained channel sandstone, $\mathbf{b}$ Quartz (Qrz) and plagioclase (Pl) ellipsoid grains and mud clasts (Mc) elongated parallel to the bedding in red-channel sandstone, c Coarse-grained lamination with Quartz (Qrz) and muscovite (Ms) in white-channel sandstone, $\mathbf{d}$ White-channel

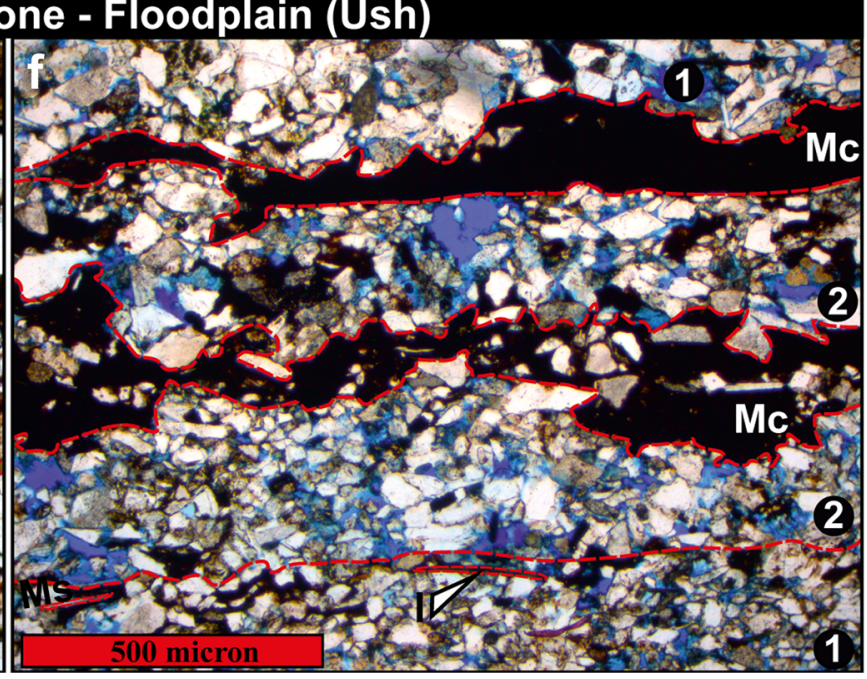

sandstone with blue dye showing alternation of (1) fine-grained, low porosity laminae and (2) coarse-grained laminae, e Sheet-like sandstone showing preferential orientation of muscovite, biotite and chlorite parallel to the bedding, f Sheet-like sandstone with blue dye showing Illite (i) and mud-clasts $(\mathrm{Mc})$ elongated parallel to the bedding and alternation of (1) fine-grained low-porosity laminae and (2) coarse-grained laminae 

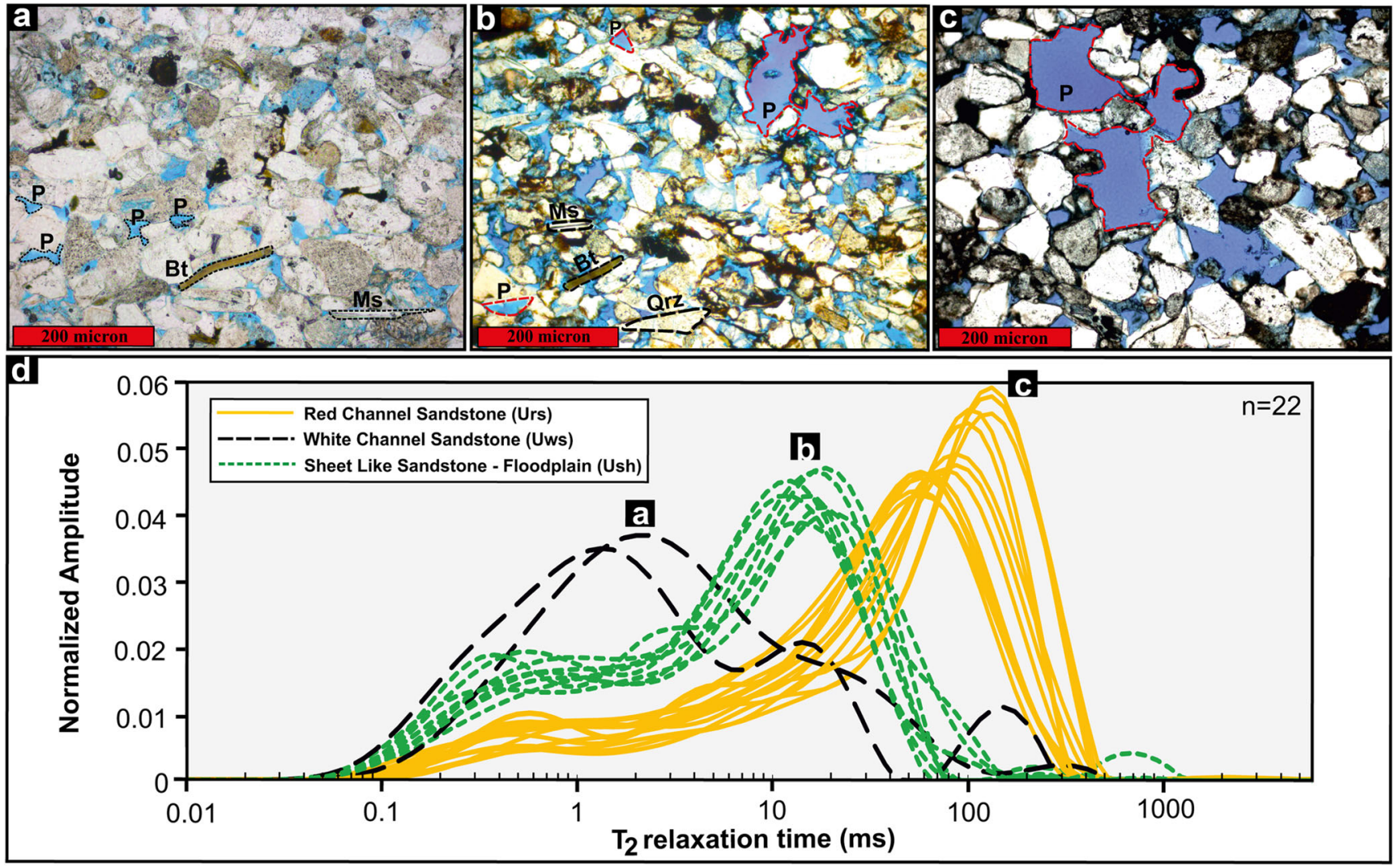

Fig. 7 Pore size and NMR data from the St Bees Sandstone Formation. a White-channel, b sheet-like, c red-channel sandstone (plane polarized light), d $T_{2}$ distribution in the three sedimentary units

petrophysical analyses confirm how the red-channel (Urs) sandstones are the most permeable lithology at the core-plug scale (Fig. 8a-b). There is broad agreement between matrix permeability values from shallow (up to $150 \mathrm{~m}$ ) and relatively deep (Sellafield) investigations of the St Bees Sandstone aquifer (Fig. 8c; Table 2). Core-plug scale hydraulic conductivities were measured without simulation of overburden pressure; however, this is probably not important since Daw et al. (1974) demonstrated, using multi-stage triaxial stress experiments, how intergranular core-plug scale hydraulic conductivity is only slightly reduced (by 6\%) in response to an increase in lithostatic pressure of $7 \mathrm{MPa}$, representing the overburden pressure at approximately $300 \mathrm{~m}$ below the ground surface for this lithology. However, some minor differences are evident: outcrop-derived plugs of channel-sandstone are slightly more porous and permeable than those from borehole cores (Fig. 8c; Tables 1 and 2).

\section{Well-test scale hydraulic properties of fluvial deposits}

\section{Results: shallow aquifer characterization}

Single-borehole drawdown and recovery tests were analyzed in the St Bees-Egremont area in the Bridge End Trial (BET),
Rottington Trial (RT) and West Cumbria ABH 1 (W1) wells (Fig. S2 of the ESM; Table 4), which provide hydraulic information on the shallow (10-120 m BGL) saturated part of the St Bees Sandstone aquifer. These three groundwater monitoring boreholes are characterized by similar lithostratigraphic features since all penetrate both the South and North Head members of the St Bees Sandstone Formation. Transmissivity values obtained $\left(31 \mathrm{~m}^{2} /\right.$ day for BET, $77 \mathrm{~m}^{2} /$ day for RT and $268 \mathrm{~m}^{3} /$ day for WCABH1, see Table 4) are typical for the St Bees Sandstone aquifer in West Cumbria at depths shallower than $150 \mathrm{~m}$ (see Fig. 1b). Indeed, all the transmissivity values that have been previously published from the relatively shallow St Bees Sandstone aquifer $(<150 \mathrm{~m})$ range from $\sim 10^{1}$ to $10^{3} \mathrm{~m}^{2} /$ day $\left(K \sim 10^{-1}-10^{1} \mathrm{~m} /\right.$ day $)$. Fluid temperature, conductivity and flow velocity logs for the Rottington Trial borehole (Fig. 9; Table 5) were measured while pumping at $150 \mathrm{~L} / \mathrm{min}$ from within the well casing. Fluid temperature and conductivity show sharp variation near the bottom of the borehole, representing in-flows. The main in-flow zones correspond with principal bedding fractures, identified in the acoustic log (Figs. 9 and 10). Using the overall pumping test transmissivity (Table 4) as a constraint, the flow $\log$ was analyzed using a method which allows calculation of hydraulic conductivity of individual layers selected by the user (e.g., Fienen et al. 2004; Molz et al. 1989; Parker et al. 2010). Layer hydraulic conductivity values (Fig. 9; Table 5) 

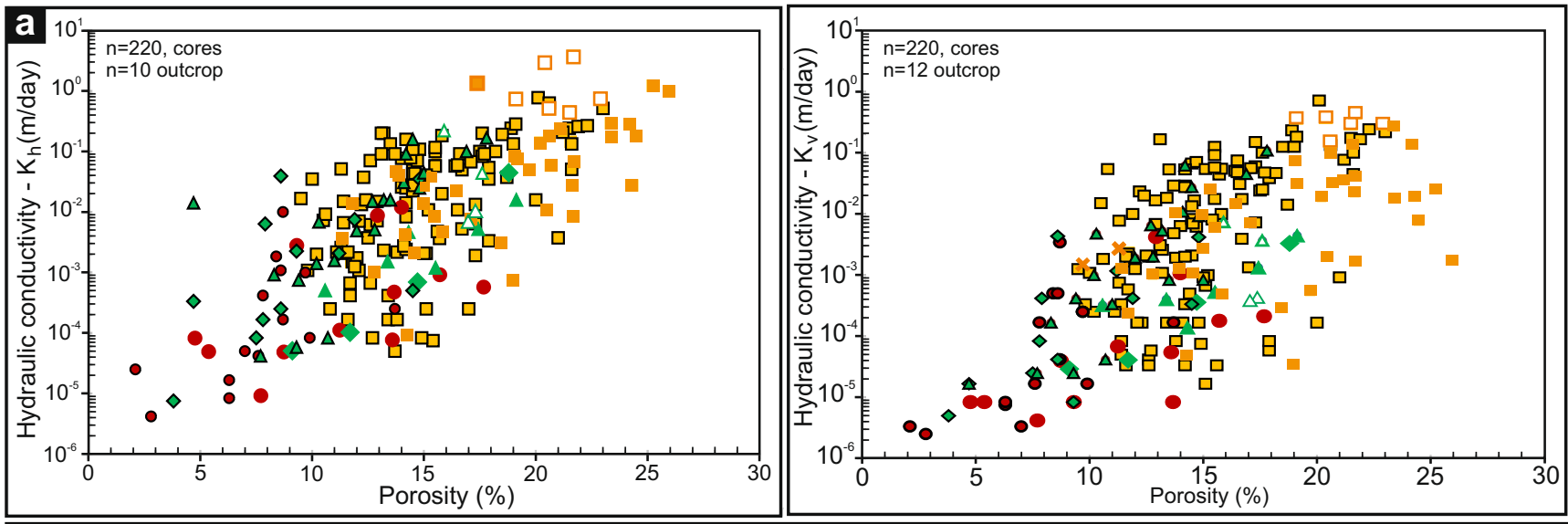

Red-channel sandstone-shallow investigation Mudstone interlayer-shallow investigation $\triangle$ Floodplain sandstone-shallow investigation $\diamond$ Floodplain mudstone-shallow investigation $\square$ Red-channel sandstone-deep investigation $\mathrm{Mudstone}$ interlayer-deep investigation $\square$ Red-channel sandstone-outcrop

Floodplain sandstone-deep investigation Floodplain mudstone-deep investigation

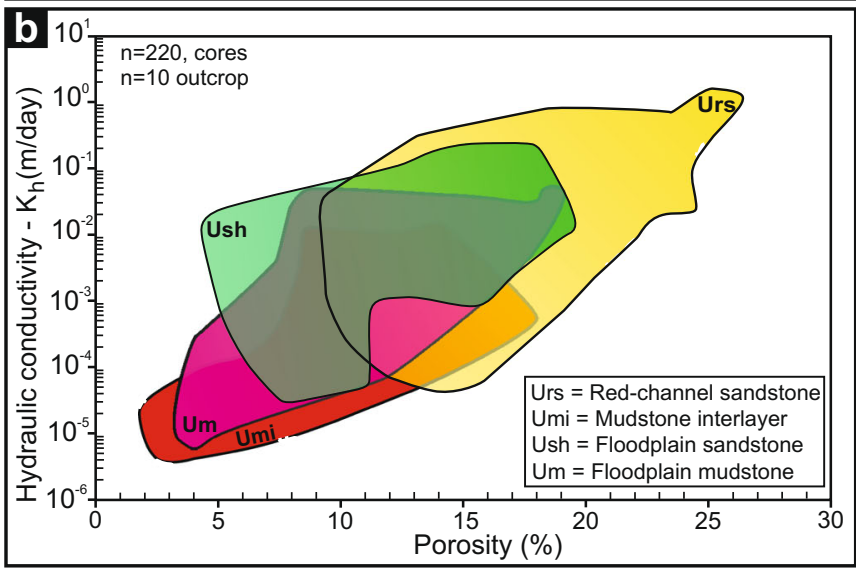
$\triangle$ Floodplain sandstone-outcrop
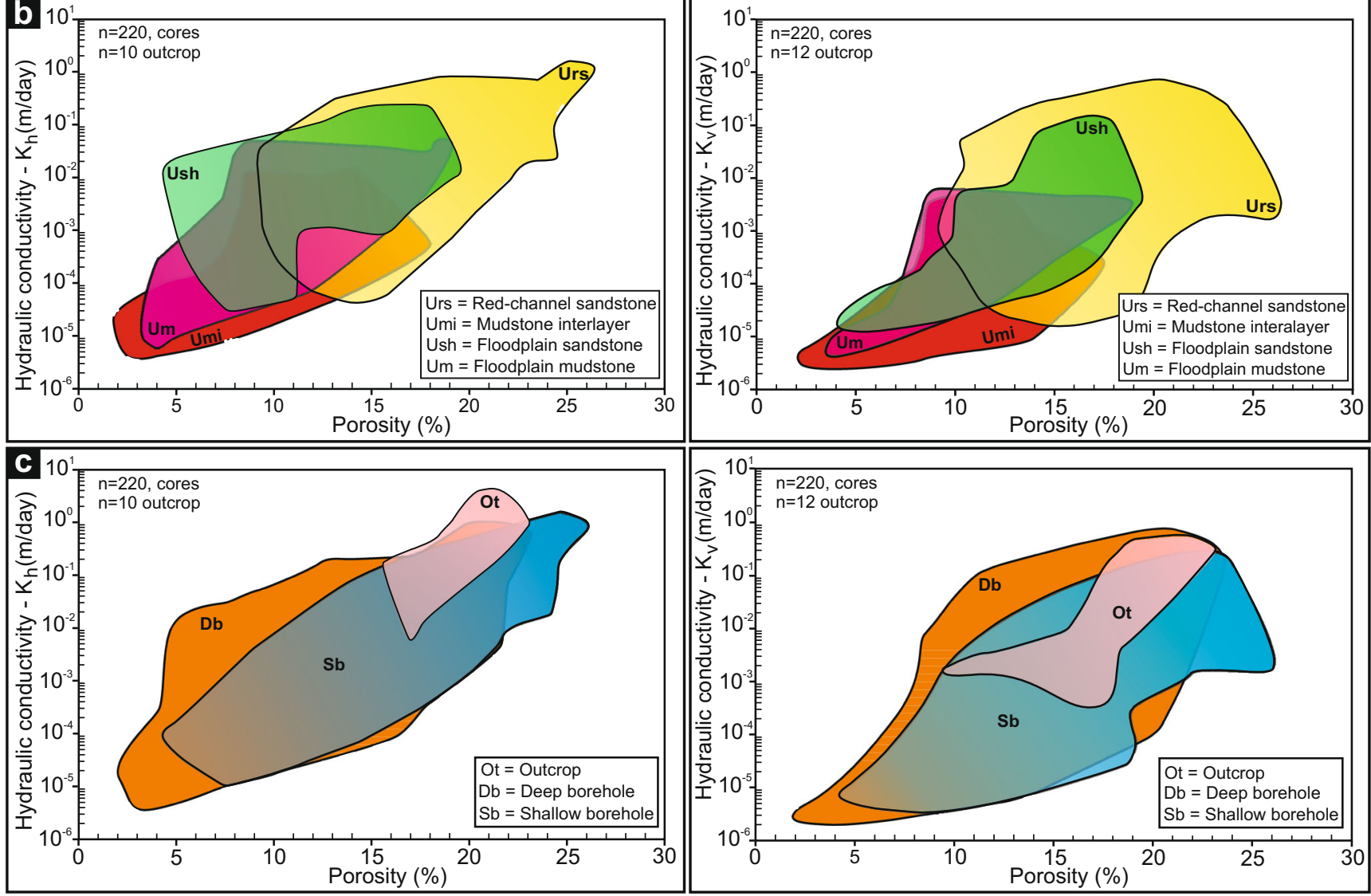

Fig. 8 Porosity-permeability semi-log plots in the St Bees Sandstone Formation based on core plugs from outcrop (Table 1, this study) and boreholes (Tables 2 and 3, previous studies): left panels show $K_{h}$, right panels $K_{v}$ a data points distinguishing channel sandstone, mudstone

range up to $2.6 \mathrm{~m} /$ day. Additionally, all the conductive flow zones (with the exception of the layer L5 which is characterized by abundant calcite veins seen in the acoustic log, which fill fractures, thereby preventing fracture flow) show hydraulic conductivity values (Table 5) which are between one $\left(10^{1}\right)$ and two $\left(10^{2}\right)$ orders of magnitude higher than core-plug scale interlayers (interbedded in channel sandstone), floodplain sandstone and floodplain mudstone, b Porosity-permeability fields defined by the different sedimentary units, $\mathbf{c}$ Porosity-permeability fields according to samples from outcrop, shallow and deep boreholes

average (geometric mean) values (Table 3) for the channel sandstone (Urs) facies, which represents the main lithology penetrated by the Rottington Trial well. Thus, the comparison of the upscaled plug-matrix hydraulic conductivities with those derived from the pumping test and flow-log/acoustic log analysis indicates that bedding-parallel fractures, rather than the 


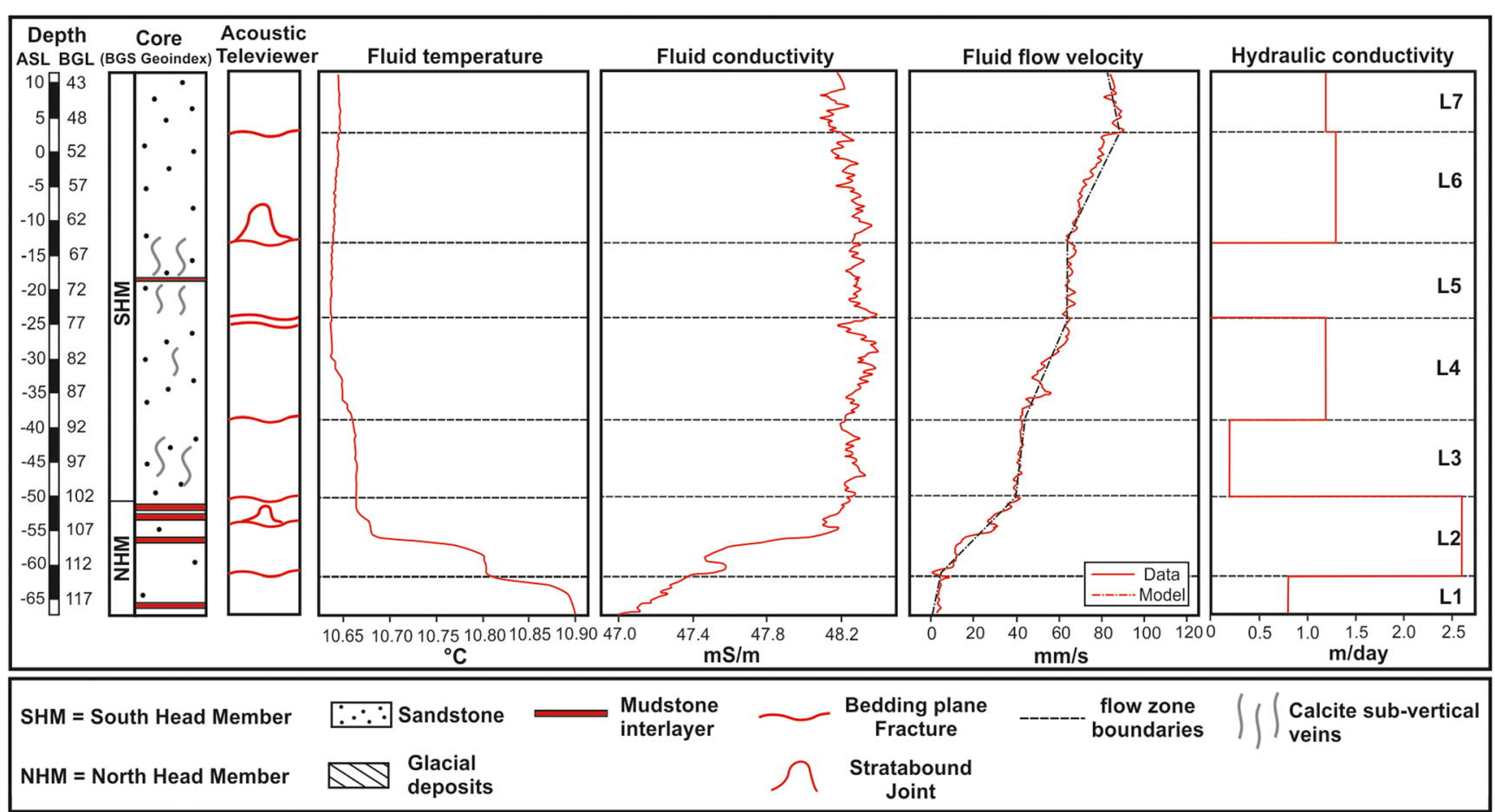

Fig. 9 Rottington Trial well fluid log analysis. Fluid temperature, conductivity, fluid flow velocity, all under pumped conditions, and interpreted layer hydraulic conductivities

matrix, act as the main pathways for groundwater flow in the shallow St Bees Sandstone aquifer. Additionally, other elements indicate fractures as main flow drivers of water flowfor example, the L2 flow zone located within the NHM is characterized by the most abundant occurrence of relatively impermeable mudstone beds (Fig. 9; Table 3) but also the most permeable zone, suggesting that the matrix cannot represent the dominant flow pathway. The particularly high hydraulic conductivity ( $K=2.6 \mathrm{~m} /$ day) of the $\mathrm{L} 2$ flow zone may be related to the strongly layered nature of this $\sim 10 \mathrm{~m}$ stratigraphic interval. In fact, the L2 zone penetrates several bedding discontinuities $(n=6)$ localized in correspondence of the contact between sandstone and mudstone deposits. Also, the L2 zone penetrates the junction between a bedding fracture and a stratabound joint which further enhances flow in this highly conductive zone; fluid temperature, conductivity and flow velocity show rapid change at $105 \mathrm{~m}$ BGL (Figs. 9 and 10b) in correspondence with this tectonic structure (a bedding plane fracture connected to a vertical joint, which may be similar, is shown in outcrop in Fig. 4a). Similarly, the L6 zone in the RT well (Fig. 10a) is bounded at the base by a cluster of bedding-parallel fractures and sub-vertical stratabound joints which correspond to an inflow point (characterized by a sharply increasing flow velocity).

\section{Results: intermediate and deep aquifer characterization}

Packer tests, fluid temperature and conductivity logs were obtained from the BGS archive for the two Sellafield deep boreholes (Fig. 11 and Fig. S2 of the ESM; BH2 and BH3 wells). The St Bees Sandstone aquifer is intercepted between 150 and $400 \mathrm{~m}$ BGL in the Sellafield BH2 well and between 672 and 1,100 m BGL in the BH3 well (Fig. 1; Table 4). The fluvial St Bees Sandstone Formation is present in the $\mathrm{BH} 2$ and BH3 wells below the highly permeable aeolian deposits of the Calder Sandstone Formation (Allen et al. 1997); thus, the aeolian deposits of the Calder Sandstone are not intercepted by the open screen of the BH2 and BH3 wells (Table 4). However, both the boreholes (BH2, BH3) intercept the entire St Bees Sandstone aquifer, including the North Head Member, which has relatively abundant mudstone beds, and is characterized by higher gamma-ray and lower neutron porosity values than the South Head Member (Fig. S3 of the ESM). Hence, these two deep boreholes allow investigation of the hydraulic properties of the St Bees Sandstone aquifer at relatively elevated depths up the geological boundary between the Sherwood Sandstone and underlying Permian deposits (Fig. 1). The two long-screen well tests (BH2 1, BH3 1) tested > 300-m intervals that fully penetrate the St Bees Sandstone aquifer but that also penetrate underlying Permian deposits. The latter sedimentary deposits represent 27 and $28 \%$ of the screen lengths in the $\mathrm{BH} 2$ and $\mathrm{BH} 3$ longinterval tests, respectively; however, short-interval tests $(<$ $25 \mathrm{~m}$ ) were also conducted at selected elevations within the South Head Member, which is dominated by channelized architectural elements in the Sellafield $\mathrm{BH} 2$ and $\mathrm{BH} 3$ core logs.

Analysis of the recovery data phases of both short- and longinterval tests yield transmissivities of 0.53 and $0.70 \mathrm{~m}^{2} /$ day 
Fig. 10 Amplitude and travel time acoustic logs in the shallow St Bees Sandstone aquifer showing intersection of bedding plane fractures $(\mathrm{Bf})$ and vertical stratabound joints $(\mathrm{J})$ in the Rottington Trial well occurring at $\mathbf{a} \sim 66.5 \mathrm{~m}$ BGL and, $\mathbf{b} \sim 105.5 \mathrm{~m}$ BGL
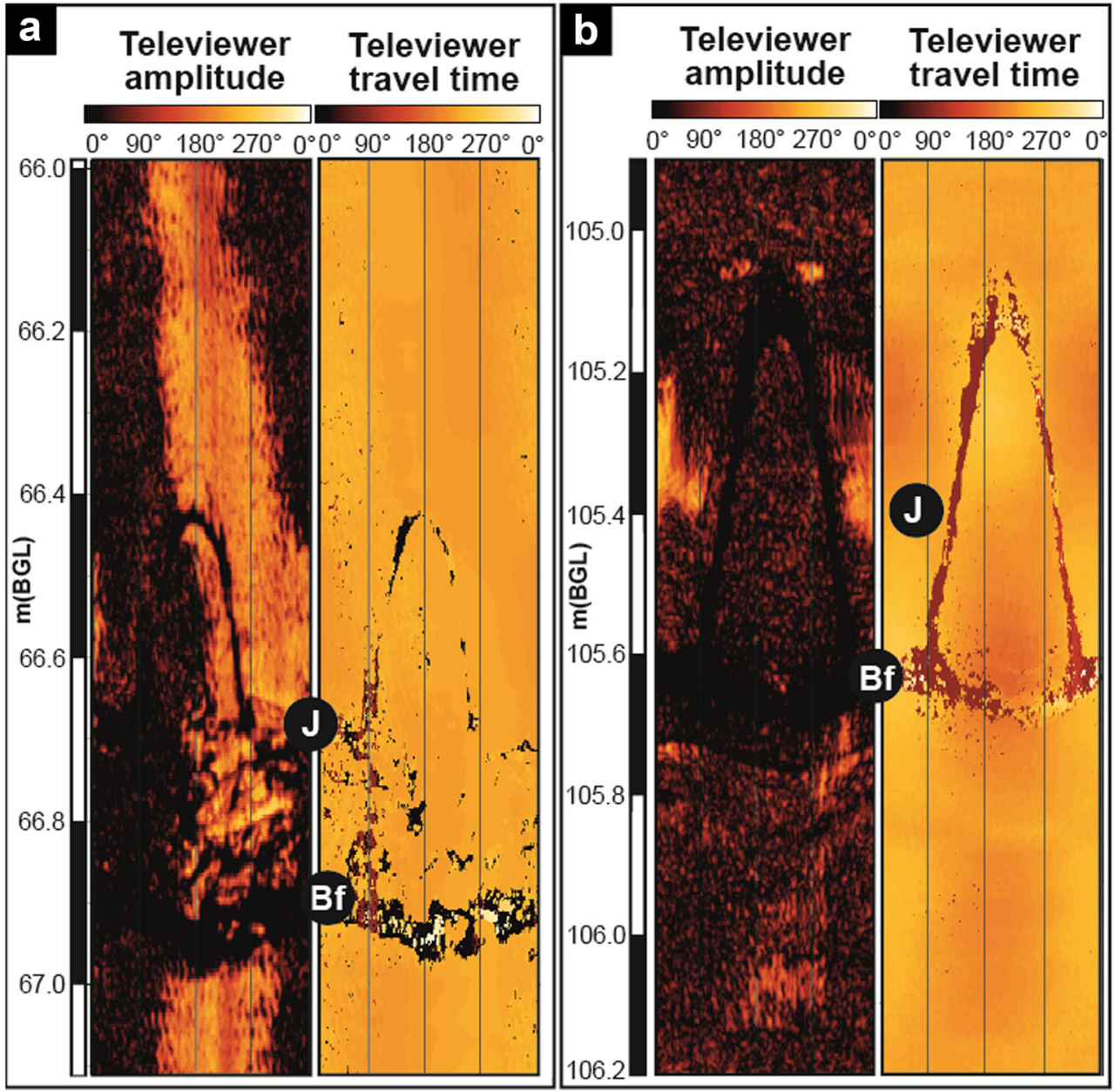

(equivalent mean $K$ of $2.3 \times 10^{-2} \mathrm{~m} /$ day and $2.0 \times 10^{-3}$ for $\mathrm{BH} 2$ test s and BH2 test 1, respectively) in Sellafield BH2 (intermediate depth aquifer). However, analysis of the recovery yields transmissivities of 0.04 and $0.41 \mathrm{~m}^{2} /$ day (equivalent mean $K$ of $4.0 \times 10^{-3}$ and $6.4 \times 10^{-4} \mathrm{~m} /$ day for BH2 test s and BH2 test 1 , respectively) in Sellafield BH3 (deep aquifer). Based on the short-interval tests that exclusively penetrate St Bees Sandstone, values of hydraulic conductivity are thus $\sim 10^{-2}$ and $10^{-3} \mathrm{~m} /$ day for the intermediate (BH2) and deep (BH3) tests, respectively.

Sellafield $\mathrm{BH} 2$ and $\mathrm{BH} 3$ tests yield mean well-test-scale hydraulic conductivity values that are significantly lower (by a factor of $\sim 10^{2}-10^{3}$ ) with respect to the wells tested in the shallower aquifer in the Bridge End Trial, Rottington Trial and West Cumbria ABH1 wells (Table 4). However, analysis of fluid logs from the deep aquifer here reveals a residual contribution of fractures to flow, as sharp changes in fluid temperature and conductivity logs occur in correspondence of fractures (Fig. 11). The BH2 log (Fig. 11a) also shows sharp changes in fluid temperature and conductivity at 327,335 and $358 \mathrm{~m}$ BGL in correspondence of vertical joints bounded by bedding fractures. Sellafield $\mathrm{BH} 3$ temperature and conductivity logs show inflows associated with bedding plane fractures and normal faults (Fig. 11b).
The shallow St Bees Sandstone aquifer is characterized by low values of fluid conductivity $(\sim 50 \mathrm{mS} / \mathrm{m})$ representative of freshwater, as seen in the Rottington Trial and other wells in the part of the aquifer covered only by superficial deposits (see previously logged wells in Fig. 1b). Sellafield BH2 shows freshwater conductivity down to $315 \mathrm{~m}$ BGL but saline water $(\sim 600 \mathrm{mS} / \mathrm{m})$ at about $350 \mathrm{~m}$ BGL (Fig. 11a). The well-testscale hydraulic conductivity $\left(K=2.3 \times 10^{-2} \mathrm{~m} /\right.$ day from $\sim 200 \mathrm{~m}$ BGL, test BH2s; see Table 4) may indicate that fracture alteration is not well developed here compared to that in the shallower aquifer (cavities have been detected by using optical televiewer logs at depths < $150 \mathrm{~m}$ BGL; see previously logged boreholes in Fig. 1b). The Sellafield BH3 well (Fig. 11b) is characterized by conductivity values of $\sim 10^{4}$ $\mathrm{mS} / \mathrm{m}$, i.e. representative of particularly high salinity brines; thus, the aquifer intercepted by $\mathrm{BH} 3$ has seen no freshwater circulation, which is unsurprising considering its down-dip location (see Fig. 1b). Fluid logs in BH3 at depths around $850 \mathrm{~m}$ BGL are characterized by less frequent slope changes with respect to those from $\mathrm{BH} 2$ at depths ranging up to $400 \mathrm{~m}$ BGL (Fig. 11a-b). Significant changes in conductivity seems to occur only in correspondence of normal faults at $\sim 850$ and $\sim 950 \mathrm{~m}$ BGL in BH3 well, although both tested intervals in 

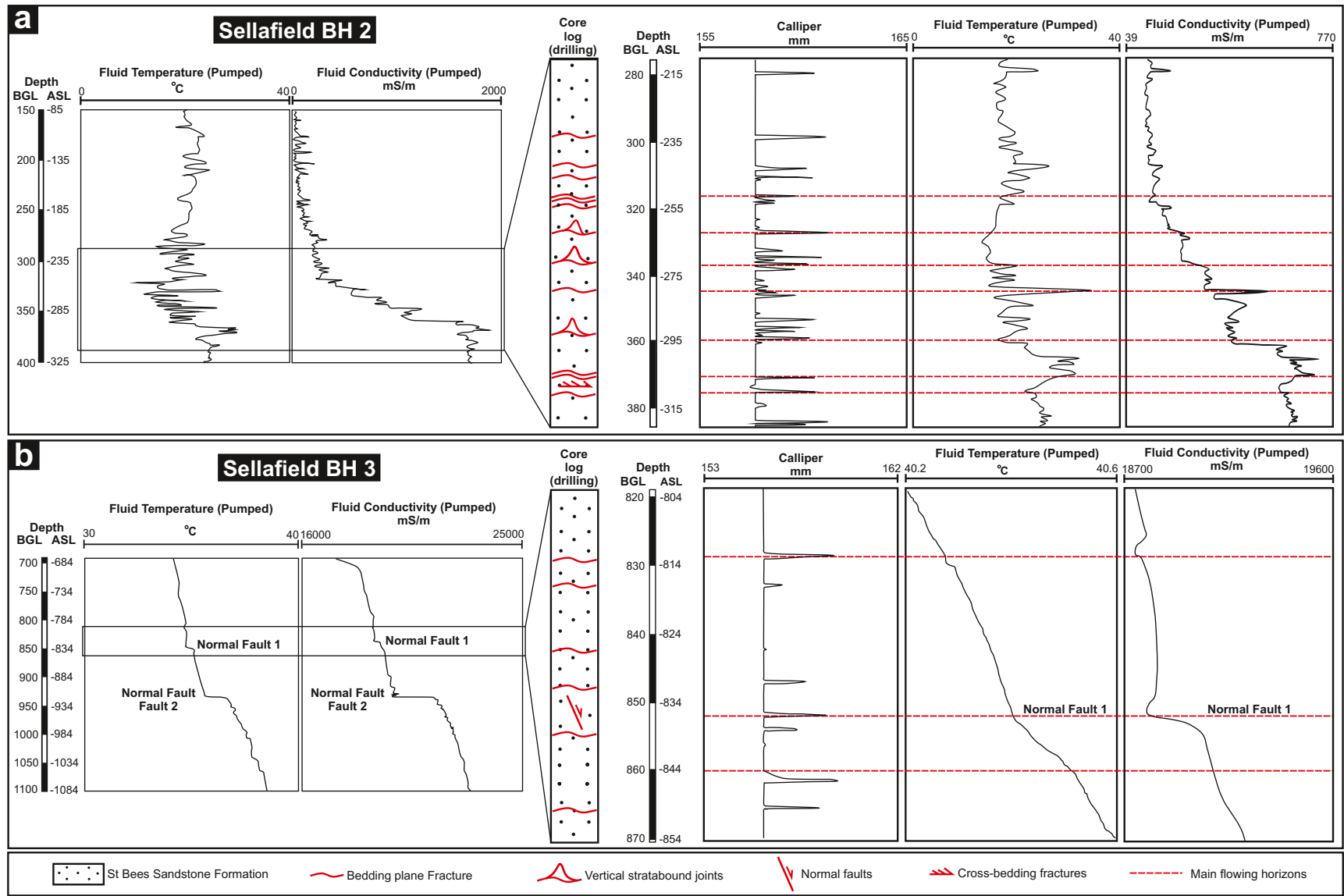

Fig. 11 Fluid-logs from selected intervals in the intermediate and deep St Bees Sandstone aquifer respectively. Fluid conductivity and temperature under pumped conditions for a Sellafield BH 2 and b Sellafield BH 3

BH2 and BH3 (Fig. 11a-b) are characterized by bedding plane and stratabound fractures.

\section{Results: core-plug upscaling for the deep aquifer}

Horizontal hydraulic conductivity $\left(K_{\mathrm{h}}\right)$ from channel sandstone plugs cored in correspondence with pumped intervals of the short-interval length tests for Sellafield $\mathrm{BH} 2$ and BH3 were upscaled to give predicted transmissivity values based on the matrix flow component (Table 6). Results from the $\mathrm{K}_{\mathrm{h}}$ geometric mean upscaling and measured well test transmissivities agree to within the same order of magnitude, although well test transmissivity is higher than upscaled transmissivity, most notably for the intermediate depth test (BH2s). Use of geometric mean (instead of arithmetic mean) to simulate horizontal flow is supported by the log-normal distribution of channel core plugs shown in Fig. S4 of the ESM (Maliva and Missimer 2010; Zheng et al. 2000). This result is commensurate with analysis of fluid logs, which suggest large bedding fractures bounded by stratabound joints contribute to flow. Thus, the deep St Bees Sandstone aquifer (150-1,100 m BGL) is likely to act as a dual permeability aquifer. The ratio $\left(T_{\text {well-test }} / T_{\text {upscaled }}\right)$ between well test and upscaled transmissivity decreases from 2.8 to 1.3 at increasing depth (from $\mathrm{BH} 2 \mathrm{~s}$ to $\mathrm{BH} 3 \mathrm{~s}$ test intervals).

Table 6 Comparison of upscaled transmissivity based on geometric means from core plugs, versus well-test transmissivity, for short interval tests in Sellafield $B H 2 s$ and $B H 3 s$ (intermediate and deep St Bees Sandstone aquifer respectively, see Table 4)

\begin{tabular}{|c|c|c|c|c|c|c|c|}
\hline $\begin{array}{l}\text { Field site/borehole } \\
\text { name }\end{array}$ & $\begin{array}{l}\text { Plugs } \\
(n)\end{array}$ & $\begin{array}{l}\text { Screen length } \\
\text { (m) }\end{array}$ & $\begin{array}{l}\text { Screen interval } \\
(\mathrm{m} \mathrm{BGL})\end{array}$ & $\begin{array}{l}K_{\mathrm{h}}, \\
\text { Geometric mean } \\
\text { plugs (m/day) }\end{array}$ & $\begin{array}{l}K_{\mathrm{v}}, \\
\text { Harmonic mean } \\
\text { plugs (m/day) }\end{array}$ & $\begin{array}{l}\text { Field measured } \\
\text { transmissivity } \\
\left(\mathrm{m}^{2} / \text { day }\right)\end{array}$ & $\begin{array}{l}\text { Upscaled } \\
\text { transmissivity } \\
\text { from cored plugs } \\
\left(\mathrm{m}^{2} / \text { day }\right)\end{array}$ \\
\hline $\mathrm{BH} 2 \mathrm{~s}$ test & 8 & 23 & $200-223$ & $5.6 \times 10^{-3}$ & $4.7 \times 10^{-4}$ & 0.53 & 0.19 \\
\hline $\mathrm{BH} 3 \mathrm{~s}$ test & 4 & 10 & 931-941 & $2.7 \times 10^{-3}$ & $9.5 \times 10^{-4}$ & 0.04 & 0.03 \\
\hline
\end{tabular}




\section{Discussion}

\section{Effect of sedimentary and diagenetic heterogeneity on matrix properties}

Comparison of the cement species of the reddish/yellowish lithotypes (which are represented by sheet-like sandstone (Ush) and red-channel sandstone (Uws)) against the whitesilty sandstone (Uws) suggests that the latter sedimentary unit represents a heterogeneity of diagenetic origin. The paucity of hematite cement $(0-2 \mathrm{wt} \%)$ in the white-silty sandstone and its abundance in the sheet-like sandstone and red-channel sandstone (5-20 wt\%) demonstrates how the white-silty sandstone (Uws) represents a locally reducing zone, examples of which typically extend laterally for up to $10 \mathrm{~m}$ (Fig. 3c; Jones and Ambrose 1994) in a succession that is otherwise dominated by oxidizing conditions. Indeed, oxic conditions were dominant in the arid Triassic environments that were widespread across NW Europe at the time of deposition of the St Bees Sandstone Formation (Brookfield 2008; McKie and Williams 2009; McKie and Shannon 2011). Such whitesandstone layers are common within fluvial red-bed deposits more widely; they are recognized in several regions across Europe, North Africa, South and North America (Beitler et al. 2005; Bourquin et al. 2010; Costamagna 2012; Michalzik 1991; Waugh 1973)-for example in the Triassic of the North German Basin they were interpreted as areas locally characterized by reducing conditions which were triggered by oxidation of organic material at early diagenetic stages (Weibel 1998; Weibel and Friis 2004). The low porosity and permeability, and the small-pore size distribution (indicated by SEM, optical microscope and $T_{2}$ values) of the white-silty sandstone (Uws) may have protected these reducing areas from oxidizing fluids during later diagenetic stages.

\section{Effect of burial history and exhumation}

The burial history of the St Bees Sandstone aquifer around Sellafield was investigated by Chadwick et al. (1994), who reconstructed palaeo-temperatures from apatite minerals from the BH3 borehole. Backstripping curves show how the St Bees Sandstone Formation was rapidly buried below $2 \mathrm{~km}$ in the early Triassic, and then up to a $4 \mathrm{~km}$ depth during the Cretaceous (Chadwick et al. 1994). Since this period, the formation has been exhumed reaching its current depth in the early Quaternary; thus, the St Bees Sandstone aquifer was exposed to weathering and to the current flow conditions in its vadose and shallow saturated zones during the last 2.5 Ma. During the Quaternary, intense weathering developed up to $\sim 10 \mathrm{~m}$ below the overlying glacial till; this was recognized in the St Bees Sandstone aquifer by McMillan et al. (2000) and Hough et al. (2006). Additionally, acidic conditions $(\mathrm{pH}=5)$ capable of dissolving calcite are common in the unsaturated zone (such low $\mathrm{pH}$ can be generated by high levels of dissolved $\mathrm{CO}_{2}$ produced by bacterial respiration in the soil zone) of the UK Sherwood Sandstone aquifer (Moss and Edmunds 1992; Tellam and Barker 2006). This work shows how samples collected $\sim 5-10 \mathrm{~m}$ below the glacial till (see Fig. 8c, outcrop samples) are characterized by porosity and permeability enhancement compared to samples from boreholes, i.e. removal of calcite, which represents an important component filling pores in the samples from the deeper, saturated aquifer (Strong et al. 1994; Waugh 1978). Thus, 2.5 Ma exposure to weathering created a very shallow matrix alteration zone of enhanced porosity and permeability up to $\sim 10 \mathrm{~m}$ below the Quaternary till (schematically illustrated in Fig. 12a). Acoustic televiewer logs show that stratabound joints pervade the St Bees Sandstone aquifer; these probably arise due to the lithospheric uplift of NW Europe. Stratabound fractures typically characterize the outcropping Sherwood Sandstone Group across all the UK Triassic basins (Allen et al. 1998; Hitchmough et al. 2007; Wealthall et al. 2001). Additionally, core logs from the deep Sellafield boreholes (Nirex 1996a, b) indicate how such stratabound fractures exist up to $\sim 1 \mathrm{~km}$ depth in the St Bees Sandstone aquifer. This is consistent with previous studies on unloading joints in NW Europe; for example, mining data indicate bed-bound joints at $\sim 350 \mathrm{~m}$ BGL (Tratman 1967). Also, numerical models suggest the transition between stratabound and nonstratabound joints typically occurs between 0.6 and $2.0 \mathrm{~km}$ (Gillespie et al. 2001). Optical logs in the shallow St Bees Sandstone aquifer $(<150 \mathrm{~m} \mathrm{BGL})$ also show development of karst pathways in correspondence of intersections between bedding planes and stratabound fractures (Medici et al. 2016). This suggests how $\sim 2.5$ Ma of exposure to the processes of enhancement of fracture permeability, typical of shallow aquifers, might have played a key role in influencing transmissivity distribution in this fractured fluvial aquifer, which is markedly decreased where tested at depths $>150 \mathrm{~m}$ below the ground surface (Chadwick et al. 1994; Streetly et al. 2000; Worthington et al. 2016). Hence, a second groundwater alteration zone in the aquifer (see Fig. 12) is recognized, below the upper $10 \mathrm{~m}$, that shows matrix porosity enhancement. This second alteration zone is characterized by development of karst-like features related to flowing fractures which were detected up to $150 \mathrm{~m}$ BGL in this study (as illustrated schematically in Fig. 12). Here, high groundwater flow occurs in the St Bees Sandstone aquifer, i.e. recharge of freshwater (with low $\mathrm{pH}$ and electrical conductivity $\sim 50 \mathrm{mS} / \mathrm{m}$ ) driven by a topographic gradient dissolves the calcite which represents an important cement specie in the saturated zone of the aquifer.

\section{Matrix vs. fracture flow}

Bedding parallel fractures have been recognized as principal flow pathways in other shallow sandstone aquifers (also at depths $<150 \mathrm{~m}$ BGL) in several case studies across Europe and America (e.g., Bruthans et al. 2012a, b; Gellasch et al. 2013; Hitchmough et al. 2007; Leaf et al. 2012; Morin et al. 


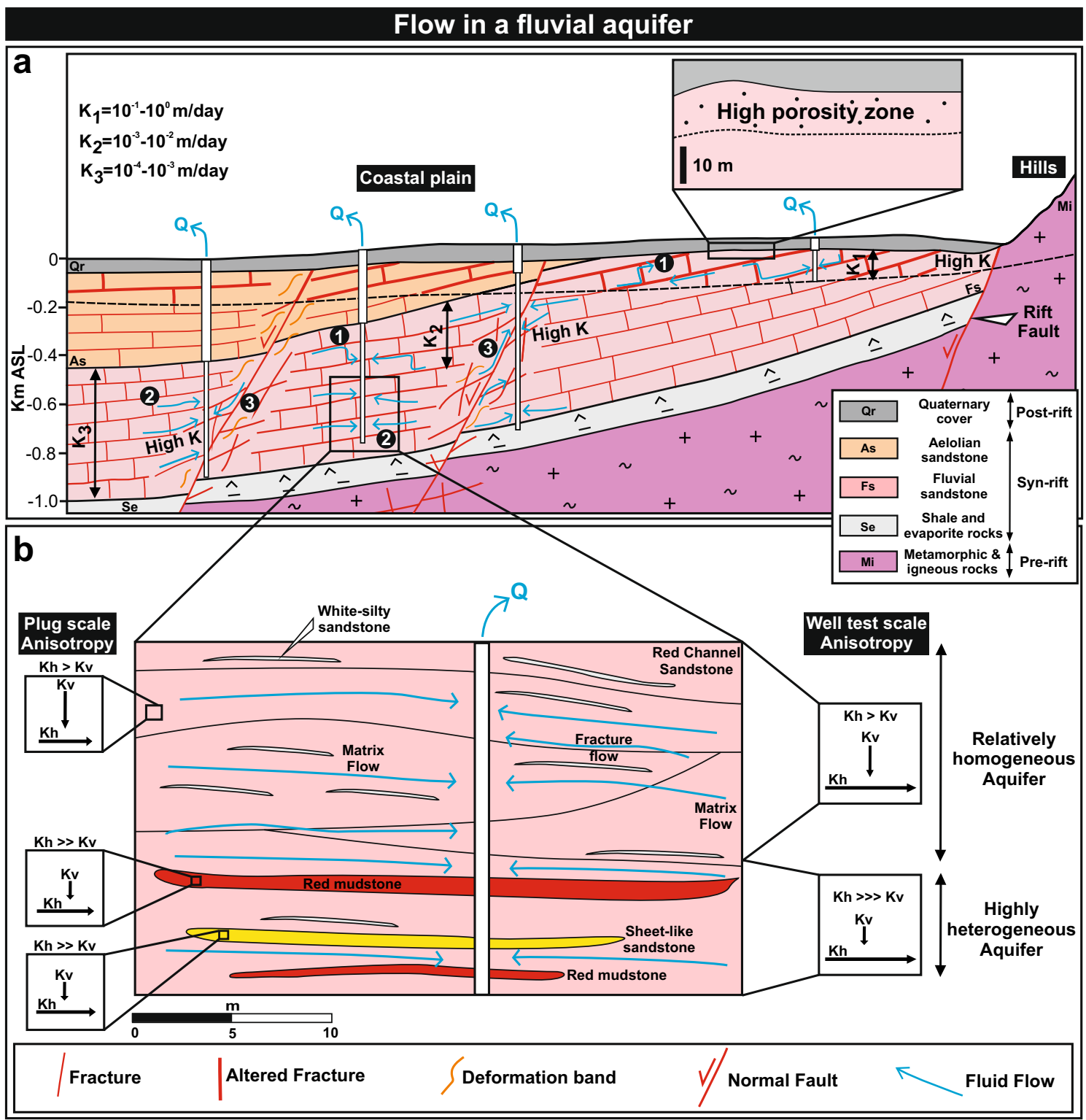

Fig. 12 Conceptual models of fluid flow to wells under pumped conditions in fluvial aquifers in a rift-type basin and resulting core-plug vs well-test scale anisotropy. a Nature of permeable pathways in a welllithified fluvial aquifer showing flow to wells through the (1) stratabound

1997; Runkel et al. 2006). However, this work shows how stratabound joints in shallow sandstone aquifers enhance flow, establishing connection between bedding plane fractures, as illustrated schematically in the conceptual model shown in Fig. 12a. Indeed, fluid and acoustic televiewer logs indicate that the major inflow zones to wells at depths $<150 \mathrm{~m}$ BGL in the St Bees Sandstone occur associated with the junctions between bedding plane and bed-bound fractures (Figs. 9 and 10). The St Bees Sandstone aquifer is characterized at shallow $(<\sim 150$ $\mathrm{m}$ BGL depths) by a zone of enhanced permeability $\left(K \sim 10^{-1}\right.$ $10^{0} \mathrm{~m} /$ day) where it is covered only by permeable glacial deposits. However, the deeper aquifer tested in Sellafield boreholes, not subjected to meteoric water circulation, is fracturing system, (2) matrix and (3) fault structures, b Enlarged panel showing sedimentary structure and flow pattern at intermediate to high depths

characterized by much lower field-scale hydraulic conductivity (by a factor of $10^{2}-10^{3}$ ). Here, the lack of meteoric water circulation is confirmed by the fact that the borehole fluid electrical conductivity is well above freshwater values (see Fig. 11).

Data from the West Cumbria ABH1 well (Table 4) located $\sim 3 \mathrm{~km}$ north of Sellafield locates the base of the enhanced permeability zone at a maximum depth of $150 \mathrm{mGBL}$; however, the enhanced permeability zone depth is not constrained in the St Bees-Egremont area further north, due to lack of deep wells (Fig. 1b). Beyond this alteration zone, where the St Bees Sandstone is buried under increasing depths of the Calder and subsequently the Ormskirk Sandstone, well-test scale permeability decreases more gradually downdip to $\sim 1 \mathrm{~km}$ BGL. 
Here, the St Bees Sandstone aquifer (Fig. 11b) is characterized by groundwater with electrical conductivity values of $\sim 10^{4}$ $\mathrm{mS} / \mathrm{m}$, i.e. representative of particularly high salinity brines that characterize the deeper parts of the eastern Irish Sea Basin (Black and Brightman 1996).

Further reduction in well-test scale permeability seen beyond depths of around $150 \mathrm{~m}$ BGL is likely to arise from fracture closure driven by lithostatic load (Jiang et al. 2009, 2010). Core-plug scale permeability experiments on fractured plugs (Daw et al. 1974; Nirex 2001) support the hypothesis that the slight permeability reduction from intermediate (150$400 \mathrm{~m}$ BGL) to deep (400-1,100 m BGL) zones arises from fracture closure with depth. Furthermore, reduction in welltest scale permeability due to fracture closure with depth is also supported by (1) reducing difference between core-plug and well-test scale permeability decreases (Table 6), and (2) fluid conductivity logs, which show fewer irregularities at elevated depths (compare Fig. 11a-b). This hypothesized change from fracture to matrix flow with increasing depth is illustrated schematically in Fig. 12a.

\section{Faults}

In contrast to bedding parallel and stratabound joints, extensional faults show a similar hydraulic behavior when intercepted by boreholes at range of depths as illustrated schematically in Fig. 12a. The quantitative analysis of well-bore flow logs from the shallow St Bees Sandstone aquifer shows that fault zones typically account for $50 \%$ of the overall transmissivity in boreholes cutting the fault planes (Medici et al. 2016). Similarly, well tests $(n=33)$ undertaken by Streetly et al. (2000) with packers in correspondence of extensional faults at intermediate $(150-400 \mathrm{~m}$ BGL) depths in Sellafield BH2 show higher well-test scale hydraulic conductivity ( $K$ of $3.76 \times 10^{-1} \mathrm{~m} /$ day) compared to the unfaulted parts of the aquifer $\left(K\right.$ of $9.2 \times 10^{-3}-2.24 \times 10^{-1} \mathrm{~m} /$ day). Fluid logs undertaken in this work shows how normal faults in this high-mechanically resistant fluvial aquifer represent favorable flow pathways up to $\sim 1 \mathrm{~km}$ depth (Fig. 11b), typical of faults characterized by relatively highly connected open fractures in their damage zones (Fig. 4b; Ball et al. 2010; Bauer et al. 2016; Bense et al. 2013; Caine et al. 1996; Ciotoli et al. 2014; Ran et al. 2014; Vignaroli et al. 2015). This structural style has been considered a typical characteristic of fluvial deposits, since the argillaceous matrix of the fluvial St Bees Sandstone Formation allows brittle failure at lower stresses with respect to better-sorted sandstone deposits of aeolian origin (Knott 1994). Note that the higher abundance of open fractures in these fault zones may also be related to the intense fault reactivation in this strongly lithified sandstone (Milodowski et al. 1998). In terms of practical applications, the presence of fault conduits at depth could potentially allow a route for contaminants from deep nuclear waste repositories situated in basement rocks to migrate upwards. It could also influence the viability of deep geothermal schemes as such faults could both allow sufficient permeability for injection/extraction, but also allow water to escape upwards.

\section{Anisotropy in the intermediate and deep St Bees Sandstone aquifer}

Core-plug scale anisotropy values from plugs (Tables 1 and 3) can be compared with those from well-test scale tests reported by Streetly et al. (2000), who analyzed packer tests at depths > $150 \mathrm{~m}$ BGL in the St Bees Sandstone aquifer using Hantush (1961) methodology. Streetly et al. (2000) analyzed two different tests penetrating the South Head and upper North Head members, respectively. The core-plug scale anisotropy $\left(K_{\mathrm{h}} / K_{\mathrm{v}}\right)$ for the channel-sandstone has a geometric mean of 3 (based on both plugs from outcrop obtained in this study and those from boreholes obtained in previous works, Tables 1 and 3). This core-plug scale average value matches the well-test scale anisotropy which ranges from 2 to 6 according to Streetly et al. (2000). Explanation for this match between core-plug and well-test scale arises from the relative homogeneity of the South Head Member, for which $95 \%$ of the succession is characterized by fluvial channel elements (Jones and Ambrose 1994; Medici et al. 2015) and for which red-mudstone units occur only rarely and exhibit lateral continuity of only up to $30 \mathrm{~m}$ (Jones and Ambrose 1994; Nirex 1997). Also, the diagenetic white-silty sandstones within the South Head Member are of restricted lateral extent $(<10 \mathrm{~m})$ (Jones and Ambrose 1994; Medici et al. 2015); thus, the low lateral continuity of the low-permeability heterogeneities, coupled with their relatively low preservation in the sedimentary record, limit their influence on large-scale anisotropy. However, large-scale anisotropy $\left(K_{\mathrm{h}} / K_{\mathrm{v}}=17-34\right.$, Streetly et al. 2000$)$ is greater in more heterogeneous units such as the upper North Head Member (75\% sandstone; $25 \%$ mudstone); this is illustrated schematically in the lower part of Fig. $12 \mathrm{~b}$, which represents a fluvial sequence in which the lower-permeability units are preserved. Notably, the well-test-scale anisotropy in the upper North Head Member is greater than that from the geometric means of core-plug values from the constituent units: mudstone interbedded in amalgamated channel deposits $\left(K_{\mathrm{h}} / K_{\mathrm{v}}=5\right)$; sheet-like sandstone $\left(K_{\mathrm{h}} / K_{\mathrm{v}}=4\right)$; floodplain mudstone $\left(K_{\mathrm{h}} / K_{\mathrm{v}}=6\right)$; see Table 3. Additionally, well-test scale anisotropy in the North Head Member exceeds those of individual plugs from channel deposits $\left(K_{\mathrm{h}} / K_{\mathrm{v}}=2-8\right)$ (Table 1$)$. This contrast between well-test and laboratory-scale anisotropy in the upper North Head Member reflects (1) much higher lateral continuity (> $200 \mathrm{~m}$ ) of low-permeability units such as mudstone interlayers typical of most fluvial successions (Ielpi and Ghinassi 2015; Medici et al. 2015; Nirex 1997), which impede vertical flow, and (2) highly permeable fluvial channels dominating the horizontal flow (see conceptual model illustrated in Fig. 12b). The influence of mudstone units that partially impede flow at the well-test scale is also supported by the $20 \%$ transmissivity reduction moving from the South Head Member to the upper North Head Member 
of the St Bees Sandstone aquifer (Streetly et al. 2000). This is likely to arise in analogous fluvial successions of Triassic age which represent productive hydrocarbon reservoirs in the North Sea (McKie and Williams 2009; Olivarius and Nielsen 2016).

The presence of conductive low-angle-inclined $\left(5-20^{\circ}\right)$ and bedding parallel fractures (Fig. 4a), which are related to the mechanical reactivation of erosional bounding surfaces of the braided fluvial-system (Jones and Ambrose 1994; Medici et al. 2015; 2016), might also enhance the large-scale anisotropy over that seen at plug-scale (as illustrated schematically in Fig. 12b).

The absence of pumping tests using observation wells prevented field-scale anisotropy quantification in the shallow aquifer ( $<150 \mathrm{~m} \mathrm{BGL}$ ); however, other shallow fractured aquifers show anisotropy values ranging from 20 to 150 due to the effect of bedding plane fractures (Boulton 1970; Chen 2000; Neuman 1975; Odling et al. 2013). Thus, it is likely that the shallow St Bees Sandstone aquifer $(<150 \mathrm{~m} \mathrm{BGL})$ is also strongly anisotropic due to the bedding parallel fractures which represent the main flowpaths, as observed in the fluid logs.

\section{Permeability vs. scale in sandstone aquifers: current knowledge and future research}

A sharp permeability increase (up to a factor of $10^{3}$ ) is recognized in this work moving from the core-plug scale to the scale of single borehole pumping tests in the shallow $(<150$ m BGL) St Bees Sandstone aquifer. In contrast, permeability is more similar between core plug, single borehole and multiborehole scale hydraulic tests at depths $\geq 150 \mathrm{~m} \mathrm{BGL}$, indicating significant contribution of matrix flow at these depths.

Regional scale (i.e. km scale) permeability values indicate the large-scale connectivity of the fracture network in sandstone aquifer types (Michael and Voss 2009). Such permeability values are not available for the St Bees Sandstone aquifer (Fig. 2).

They can be obtained by calibration of regional groundwater flow models, but also from pulse tests on wells (Maliva and Missimer 2010; Michael and Voss 2009; Noushabadi et al. 2011). These well tests involve a cyclic withdrawal of water from the pumping well followed by a shut in period, and by measurement of the resulting pressure pulse in an observation well (Noushabadi et al. 2011). Such experiments could be conducted on the St Bees Sandstone aquifer in West Cumbria using the pre-existing borehole network.

\section{Conclusions}

A multi-scale study of the St Bees Sandstone Formation, which represents a cemented fluvial succession, demonstrates how such aquifers are influenced by a range of heterogeneities of sedimentary, tectonic and weathering-related origin. Core-plug scale permeability and NMR analyses indicate how fluvial channel sandstone bodies, which dominate the St Bees Sandstone Formation, represent the most hydraulically conductive lithology. Beddingplane fractures, which are connected by uplift-induced stratabound joints, dominate the flow in the highly permeable $\left(K \sim 10^{-1}-10^{0} \mathrm{~m} /\right.$ day) shallow aquifer, tested here to a depth of $150 \mathrm{~m} \mathrm{BGL}$, which represents a zone of fracture alteration. Flow in this highly conductive zone arises from development of karstlike pathways associated with intersections of bedding-parallel and high-angle stratabound fractures, due to flow of meteoric water at these relatively shallow depths. Here, contamination hazard to water wells is relatively high in lithified fluvial aquifers because of the potential for rapid transport of contaminants, such as wastewater from leaking sewers, along such pathways.

Well-test scale permeability was at least two orders of magnitude $\left(10^{2}\right)$ lower at depths beyond the zone of fracture alteration. A smaller permeability reduction is seen between the intermediate (150-400 m BGL) and deep (400-1,100 m BGL) St Bees Sandstone aquifer where pore fluid is hypersaline. Notably, differences between core-plug and well-test scale permeability, and frequency of well in-flows seen in temperature and conductivity logs, also decrease between intermediate and elevated depths. This most likely indicates how fracture closure leads to a progressively more important matrix contribution to flow with increasing depth.

Notably, this work investigates a sandstone aquifer of fluvial origin at investigation depths consistent with highly enthalpy geothermal reservoirs $(\sim 0.7-1.1 \mathrm{~km})$. At such depths, intergranular flow dominates in unfaulted areas with minor contribution to flow by bedding plane fractures. However, normal faults show consistent enhanced permeability up to $\sim 1 \mathrm{~km}$ depth. More generally, normal faults in relatively mechanically resistant fluvial deposits represent flow pathways since their large damage zones are dominated by open fractures. They therefore represent a hazard for contaminant dispersal associated with nuclear waste repositories by allowing contaminants to migrate towards shallower aquifer zones. Additionally, such normal faults can influence the viability of deep geothermal energy schemes, as they could both allow sufficient permeability for injection/extraction, but also allow fluids to escape upwards.

Acknowledgements The authors thank Total E\&P UK Limited for funding this research project. Well logging was conducted by European Geophysical Services Ltd. at shallow depths $(<150 \mathrm{~m}$ BGL). The Environment Agency (Warrington, UK) provided datasets concerning historical pumping tests. The British Geological Survey (Nottingham, UK) is thanked for provision of Nirex project data (well tests, wireline and fluid logs, core-plug scale hydraulic conductivities from the Sellafield repository) from the deep St Bees Sandstone aquifer (150-1,100 m). Simon Gebbett (Environment Agency) gave useful logistical advice during preliminary visits to the field sites. Vanessa Butterworth (University of Leeds) organized data derived from pumping tests. The results of this research also benefitted from discussions with John Tellam (University of Birmingham), Luca Colombera (University of Leeds), Noelle Odling (formerly of The University of Leeds), Massimiliano Ghinassi (University of Padova), Antoni Milodowski (British Geological Survey), Philippe Ruelland and Gérard Massonnat (Total E\&P) and Phil Merrin (United Utilities) regarding the hydrogeology of fluvial sandstone aquifers. Carlos Grattoni and Algy Kazlauciunas (both 
University of Leeds) provided guidance during laboratory analyses. Emma Farren and Mike Streetly (Environmental Solution International, ESI Consulting) are thanked for assistance with analysis of pumping tests. Finally, this work has benefitted from the constructive review comments of the journal's editor Jean-Michel Lemieux and the reviewers Thomas Missimer and Laurie Tremblay, for which we are grateful.

Open Access This article is distributed under the terms of the Creative Commons Attribution 4.0 International License (http:// creativecommons.org/licenses/by/4.0/), which permits unrestricted use, distribution, and reproduction in any medium, provided you give appropriate credit to the original author(s) and the source, provide a link to the Creative Commons license, and indicate if changes were made.

\section{References}

Abesser C, Lewis M (2015) A semi-quantitative technique for mapping potential aquifer productivity on the national scale: example of England and Wales (UK). Hydrogeol J 23:1677-1694. https://doi. org/10.1007/s10040-015-1295-5

Akhurst MC, Barnes RP, Chadwick RA, Millward D, Norton MG, Maddock RH, Kimbell GS, Milodowski AE (1998) Structural evolution of the Lake District boundary fault zone in west Cumbria, UK. Proc York Geol Soc 52:139-158

Aldinucci M, Gandin A, Sandrelli F (2008) The Mesozoic continental rifting in the Mediterranean area: insights from the Verrucano tectofacies of southern Tuscany (northern Apennines, Italy). Int J Earth Sci 97:1247-1269. https://doi.org/10.1007/s00531-0070208-9

Allen DJ, Brewerton LJ, Coleby LM, Gibbs BR, Lewis MA, MacDonald AM, Wagstaff SJ, Williams AT (1997) The physical properties of major aquifers in England and Wales. BGS WD/97/34, British Geological Survey, Nottingham, UK

Allen DJ, Bloomfield JP, Gibbs BR, Wagstaff SJ (1998) Fracturing and the hydrogeology of the Permo-Triassic sandstones in England and Wales. BGS WD/97/34. British Geological Survey, Nottingham

Ambrose K, Hough E, Smith NJ, Warrington G (2014) Lithostratigraphy of the Sherwood Sandstone Group of England, Wales and southwest Scotland. British Geological Survey, Nottingham, UK

Ameen MS (1995) Fractography and fracture characterization in the Permo-Triassic sandstones and the lower Palaeozoic basement, west Cumbria, UK. Geol Soc Lond Spec Publ 92:97-147. https://doi.org/ 10.1144/GSL.SP.1995.092.01.07

Appleton PR (1993) Probabilistic safety assessment for the transport of radioactive waste to a UK repository at Sellafield. Int J Rad Mat Trans 4:205-211

Baas JH, Hailwood EA, McCaffrey WD, Kay M, Jones R (2007) Directional petrological characterisation of deep-marine sandstones using grain fabric and permeability anisotropy: methodologies, theory, application and suggestions for integration. Earth-Sci Rev 82: 101-142. https://doi.org/10.1016/j.earscirev.2007.02.003

Ball LB, Ge S, Caine JS, Revil A, Jardani A (2010) Constraining faultzone hydrogeology through integrated hydrological and geoelectrical analysis. Hydrogeol J 18:1057-1067. https://doi.org/ 10.1007/s10040-010-0587-z

Barnes RP, Ambrose K, Holliday DW, Jones NS (1994) Lithostratigraphical subdivision of the Triassic Sherwood sandstone group in West Cumbria. Proc York Geol Soc 50:51-60. https://doi. org/10.1144/pygs.50.1.51

Barrett MH, Kevin MH, Stephen P, Lerner DN, Tellam JH, French MJ (1999) Marker species for identifying urban groundwater recharge sources: a review and case study in Nottingham, UK. Water Resour 33:3083-3097. https://doi.org/10.1016/S0043-1354 (99)00021-4
Bauer H, Schröckenfuchs TC, Decker K (2016) Hydrogeological properties of fault zones in a karstified carbonate aquifer (Northern Calcareous Alps, Austria). Hydrogeol J 24:1147-1170. https://doi. org/10.1007/s10040-016-1388-9

Beitler B, Parry WT, Chan MA (2005) Fingerprints of fluid flow: chemical diagenetic history of the Jurassic Navajo sandstone, southern Utah, USA. J Sediment Res 75:547-561

Bell RG (1992) The durability of sandstone as building stone, especially in urban environments. Bull Assoc Eng Geol 29:49-60

Bense VF, Gleeson T, Loveless SE, Bour O, Scibek J (2013) Fault zone hydrogeology. Earth-Sci Rev 127:171-192. https://doi.org/10.1016/ j.earscirev.2013.09.008

Berglund S, Kautsky U, Lindborg T, Selroos JO (2009) Integration of hydrological and ecological modelling for the assessment of a nuclear waste repository. Hydrogeol J 17:95-113. https://doi.org/10. 1007/s10040-008-0399-6

Bianchi M, Liu HH, Birkholzer JT (2015) Radionuclide transport behavior in a generic geological radioactive waste repository. Groundwater 53:440-451. https://doi.org/10.1111/gwat.12171

Binley A, Winship P, West JL, Pokar M, Middleton R (2002) Seasonal variation of moisture content in unsaturated sandstone inferred from borehole radar and resistivity profiles. J Hydrol 267:160-172. https://doi.org/10.1016/S0022-1694(02)00147-6

Black JH, Brightman MA (1996) Conceptual model of the hydrogeology of Sellafield. Q J Eng Geol Hydrogeol 29:83-93. https://doi.org/10. 1144/GSL.QJEGH.1996.029.S1.06

Bloomfield JP, Gooddy D, Bright MI, Williams P (2001) Pore-throat size distributions in Permo-Triassic sandstones from the United Kingdom and some implications for contaminant hydrogeology. Hydrogeol J 9:219-230. https://doi.org/10.1007/s100400100135

Bloomfield JP, Moreau MF, Newell AJ (2006) Characterization of permeability distributions in six lithofacies from the Helsby and Wilmslow sandstone formations of the Cheshire Basin, UK. Geol Soc Lond Spec Publ 263:83-101. https://doi.org/10.1144/GSL.SP. 2006.263.01.04

Bosellini A (1989) Dynamics of Tethyan carbonate platforms. Soc Econ Paleontol Mineral Spec Publ 44:3-13

Bottrell S, Tellam JH, Bartlett R, Bartlett R, Hughes A (2008) Isotopic composition of sulfate as a tracer of natural and anthropogenic influences on groundwater geochemistry in an urban sandstone aquifer, Birmingham, UK. Appl Geochem 23:2382-2394. https://doi. org/10.1016/j.apgeochem.2008.03.012

Boulton NS (1970) Analysis of data from pumping tests in unconfined anisotropic aquifers. J Hydrol 10:369-378. https://doi.org/10.1016/ 0022-1694(70)90223-4

Bourquin S, Eschard R, Hamouche B (2010) High-resolution sequence stratigraphy of upper Triassic succession (Carnian-Rhaetian) of the Zarzaitine outcrops (Algeria): a model of fluvio-lacustrine deposits. J Afric Earth Sci 58:365-386. https://doi.org/10.1016/j.jafrearsci. 2010.04 .003

Bricker SH, Barkwith AKAP, MacDonald AM, Hughes AG, Smith M (2012). Effects of CO 2 injection on shallow groundwater resources: A hypothetical case study in the Sherwood Sandstone aquifer, UK. Int J Greenhouse Gas Control 11:337-348. https://doi.org/10.1016/j. ijggc.2012.09.001

Bridge JS, Tye RS (2000) Interpreting the dimensions of ancient fluvial channel bars, channels, and channel belts from wireline-logs and cores. AAPG Bull 84:1205-1228

British Geological Survey (2016) Onshore GeoIndex: geological map of Great Britain 1:650.000 scale. BGS, Nottingham, UK

Brookfield ME (2008) Palaeoenvironments and palaeotectonics of the arid to hyperarid intracontinental latest Permian-late Triassic Solway basin (UK). Sediment Geol 210:27-47. https://doi.org/10. 1016/j.sedgeo.2008.06.003

Bruthans J, Schweigstillova J, Jenc P, Churackova Z, Bezdicka P (2012a) $14 \mathrm{C}$ and $\mathrm{U}$-series dating of speleothems in the bohemian paradise 
(Czech Republic): retreat rates of sandstone cave walls and implications for cave origin. Acta Geodyn Geomat 9:93-108

Bruthans J, Svetlik D, Soukup J, Schweigstillova J, Valek J, Sedlackova M, Mayo AL (2012b) Fast evolving conduits in clay-bonded sandstone: characterization, erosion processes and significance for the origin of sandstone landforms. Geomorphology 177:178-193. https://doi.org/10.1016/j.geomorph.2012.07.02

Caine JS, Evans JP, Forster CB (1996) Fault zone architecture and permeability structure. Geology 24:1025-1028. https://doi.org/10. 1130/0091-7613

Carvalho AH, Vesely FF (2017) Facies relationships recorded in a late Paleozoic fluvio-deltaic system (Paraná Basin, Brazil): insights into the timing and triggers of subaqueous sediment gravity flows. Sediment Geol 352:45-62. https://doi.org/10.1016/j.sedgeo.2016. 12.004

Cassidy R, Comte JC, Nitsche WC, Flynn R, Ofterdinger (2014) Combining multi-scale geophysical techniques for robust hydrostructural characterisation in catchments underlain by hard rock in post-glacial regions. J Hydrol 517:715-731. https://doi.org/10.1016/ j.jhydrol.2014.06.004

Chadwick RA (1997) Fault analysis of the Cheshire Basin, NW England. Geol Soc Lond Spec Publ 124:297-313. https://doi.org/10.1144/ GSL.SP.1997.124.01.18

Chadwick RA, Kirby GA, Baily HE (1994) The post-Triassic structural evolution of north-west England and adjacent parts of the east Irish Sea. Proc York Geol Soc 50:91-102. https://doi.org/10.1144/pygs. 50.1 .91

Chen X (2000) Measurement of streambed hydraulic conductivity and its anisotropy. Environ Geol 39:1317-1324. https://doi.org/10.1007/ s002540000172

Chen Y, Durlofsky LJ, Gerritsen W, XHM (2003) A coupled local-global upscaling approach for simulating flow in highly heterogeneous formations. Adv Water Resour 26:1041-1060. https://doi.org/10. 1016/S0309-1708(03)00101-5

Ciotoli G, Bigi S, Tartarello C, Sacco P, Lombardi S, Ascione A, Mazzoli $S$ (2014) Soil gas distribution in the main coseismic surface rupture zone of the $1980, M_{S}=6.9$, Irpinia earthquake (southern Italy). J Geophys Res Solid Earth 119:2440-2461. https://doi.org/10.1002/ 2013JB010508

Clark L (1977) The analysis and planning of step drawdown tests. Q J Eng Geol Hydrogeol 10:125-143. https://doi.org/10.1144/GSL. QJEG.1977.010.02.03

Colombera L, Mountney NP, McCaffrey WD (2013) A quantitative approach to fluvial facies models: methods and example results. Sedimentology 60:1526-1558. https://doi.org/10.1111/sed.12050

Corbett PWM, Hamidreza H, Hemant G (2012) Layered fluvial reservoirs with internal fluid cross flow: a well-connected family of well test pressure transient responses. Pet Geosci 18:219-229. https://doi.org/ 10.1144/1354-079311-008

Costamagna LG (2012) Alluvial, aeolian and tidal deposits in the lower to middle Triassic "Buntsandstein" of NW Sardinia (Italy): a new interpretation of the neo-Tethys transgression. Z Dt Ges Geowiss 163: $165-183$

Daw GP, Howell FT, Woodhead GA (1974) The effect of applied stress upon the permeability of some Permian and Triassic sandstones of northern England. Int J Rock Mech Mining Sci Abstr 13:537-542

Day-Lewis FD, Johnson CD, Paillet FL, Halford KJ (2011) A computer program for flow-log analysis of single holes (FLASH). Groundwater 49:926-931. https://doi.org/10.1111/j.1745-6584. 2011.00798.x

De Simone, LA (2008) Quality of water from domestic wells in principal aquifers of the United States. US Geol Surv Sci Invest Rep 20085227

Dodge WS, Shafer JL, Guzman-Garcia AG, Noble, DA (1995) Core and log NMR measurements of an iron-rich, glauconitic sandstone reservoir. 36th Annual Symposium of SPWLA, Paris, France, 26 29 June 1995

Eden RN, Hazel CP (1973) Computer and graphical analysis of variable discharge pumping tests of wells. Civil Eng Trans, Institution of Engineers, Sydney, Australia

Fienen MN, Kitanidis PK, Watson D, Jardine P (2004) An application of inverse methods to vertical deconvolution of hydraulic conductivity in a heterogeneous aquifer at Oak Ridge National Laboratory. Math Geol 36:101-126. https://doi.org/10.1023/B:MATG.0000016232. 71993.bd

Gellasch CA, Bradbury KR, Hart DJ, Bahr JM (2013) Characterization of fracture connectivity in a siliciclastic bedrock aquifer near a public supply well (Wisconsin, USA). Hydrogeol J 21:383-399. https:// doi.org/10.1007/s10040-012-0914-7

Gillespie PA, Walsh JJ, Watterson J, Bonson CG, Manzocchi T (2001) Scaling relationships of joint and vein arrays from the Burren, Co. Clare, Ireland. J Struct Geol 23:183-201. https://doi.org/10.1016/ S0191-8141(00)00090-0

Hantush MS (1961) Drawdown around a partially penetrating well. J Proc Am Soc Civil Eng 87:83-98

Heathcote JA, Jones MA, Herbert AW (1996) Modelling groundwater flow in the Sellafield area. Q J Eng Geol Hydrogeol 29:59-S81. https://doi.org/10.1144/GSL.QJEGH.1996.029.S1.05

Hitchmough AM, Riley MS, Herbert AW, Tellam JH (2007) Estimating the hydraulic properties of the fracture network in a sandstone aquifer. J Contam Hydrol 93:38-57. https://doi.org/10.1016/j.jconhyd. 2007.01.012

Holliday HD, Jones NS, McMillan AA (2008) Lithostratigraphical subdivision of the Sherwood sandstone group (Triassic) of the northeastern part of the Carlisle Basin, Cumbria and Dumfries and Galloway, UK. Scot J Geol 44:97-110

Hossain Z, Grattoni CA, Solymar M, Fabricius IL (2011) Petrophysical properties of greensand as predicted from NMR measurements. Pet Geosci 17:111-125. https://doi.org/10.1144/1354-079309-038

Houben GJ (2015) Review: hydraulics of water wells-head losses of individual components. Hydrogeol J 23:1659-1675. https://doi. org/10.1007/s10040-015-1313-7

Hough E, Pearce JM, Kemp SJ, Williams GM (2006) An investigation of some sediment-filled fractures within redbed sandstones of the UK. Proc York Geol Soc 56:41-53. https://doi.org/10.1144/pygs.56.1.41

Huysmans M, Dassargues A (2006) Stochastic analysis of the effect of spatial variability of diffusion parameters on radionuclide transport in a low permeability clay layer. Hydrogeol J 14:1094-1106

Ielpi A, Ghinassi M (2015) Planview style and palaeodrainage of Torridonian channel belts: Applecross formation, Stoer peninsula, Scotland. Sediment Geol 325:1-16. https://doi.org/10.1016/j. sedgeo.2015.05.002

Jackson MD, Ann HM, Shuji Y, Johnson HD (2003) Upscaling permeability measurements within complex heterolithic tidal sandstones. Math Geol 35:499-520. https://doi.org/10.1023/A:1026236401104

Jiang XW, Wan L, Wang XS, Hu BX (2009) Estimation of fracture normal stiffness using a transmissivity-depth correlation. Int J Rock Mech Min Sci 46:51-58. https://doi.org/10.1016/j.ijrmms.2008.03. 007

Jiang XW, Wang XS, Wan L (2010) Semi-empirical equations for the systematic decrease in permeability with depth in porous and fractured media. Hydrogeol J 18:839-850. https://doi.org/10.1007/ s10040-010-0575-3

Jones NS, Ambrose K (1994) Triassic sandy braidplain and aeolian sedimentation in the Sherwood sandstone Group of the Sellafield area, West Cumbria. Proc York Geol Soc 50:61-76. https://doi.org/10. 1144/pygs.50.1.61

Knott SD (1994) Fault zone thickness versus displacement in the PermoTriassic sandstones of NW England. J Geol Soc 151:17-25. https:// doi.org/10.1144/gsjgs.151.1.0017 
Lawrence A, Stuart M, Cheney C, Jones N, Moss R (2006) Investigating the scale of structural controls on chlorinated hydrocarbon distributions in the fractured-porous unsaturated zone of a sandstone aquifer in the UK. Hydrogeol J 14:1470-1482. https://doi.org/10.1007/ s10040-006-0068-6ambrose

Leaf AT, Hart DJ, Bahr JM (2012) Active thermal tracer tests for improved hydrostratigraphic characterization. Groundwater 50:726735. https://doi.org/10.1111/j.1745-6584.2012.00913.x

Lewin K, Young CP, Bradshaw K, Fleet M, Blakey NC (1994) Landfill monitoring investigations at Burnstump Landfill, Sherwood Sandstone, Nottingham. CWM 035/ 9, Final report for the Department of the Environment, Bristol, UK

Lo HC, Chen PJ, Chou PY, Hsu SM (2014) The combined use of heatpulse flowmeter logging and packer testing for transmissive fracture recognition. J Appl Geophys 105:248-258. https://doi.org/10.1016/ j.jappgeo.2014.03.025

Maliva, RG, Missimer TM (2010) Aquifer storage and recovery and managed aquifer recharge using wells: planning, hydrogeology, design and operation. Schlumberger, Houston, TX

Martin CD, Christiansson R (2009) Estimating the potential for spalling around a deep nuclear waste repository in crystalline rock. Intern J Rock Mech Mining Sci 46:219-228. https://doi.org/10.1016/j. ijrmms.2008.03.001

Mathias SA, Lindsay CT (2010) Step-drawdown tests and the Forchheimer equation. Water Resour Res. https://doi.org/10.1029/ 2009WR008635

Mathias SA, Adrian B, Hongbin Z (2008) Approximate solutions for Forchheimer flow to a well. J Hydraul Eng 134:318-1325. https:// doi.org/10.1061/(ASCE)0733-9429

McKie T, Shannon PM (2011) Comment on "The Permian-Triassic transition and the onset of Mesozoic sedimentation at the northwestern peri Tethyan domain scale: Palaeogeographic maps and geodynamic implications" by S. Bourquin, A. Bercovici, J. López-Gómez, JB Diez, J. Broutin, A. Ronchi, M. Durand, A. Arché, B. Linol and F. Amour. [Palaeogeography, Palaeoclimatology, Palaeoecology 299 (2011) 265-280]. Palaeogeogr Palaeoclimatol Palaeoecol 311: 136-143. https://doi.org/10.1016/j.palaeo.2011.07.016

McKie T, Williams B (2009) Triassic palaeogeography and fluvial dispersal across the northwest European basins. Geol J 4:711-741. https://doi.org/10.1002/gj.1201

McMillan AA, Heathcote JA, Klinck BA, Shepley MG, Jackson CP, Degnan PJ (2000) Hydrogeological characterization of the onshore quaternary sediments at Sellafield using the concept of domains. Q J Eng Geol Hydrogeol 33:301-323. https://doi.org/10.1144/qjegh.33. 4.301

Medici G, Boulesteix K, Mountney NP, West LJ, Odling NE (2015) Palaeoenvironment of braided fluvial systems in different tectonic realms of the Triassic Sherwood Sandstone Group, UK. Sediment Geol 329:188-210. https://doi.org/10.1016/j.sedgeo.2015.09.012

Medici G, West LJ, Mountney NP (2016) Characterizing flow pathways in a sandstone aquifer: tectonic vs sedimentary heterogeneities. J Contam Hydrol 194:36-58. https://doi.org/10.1016/j.jconhyd. 2016.09.008

Megawati M, Madland MV, Hiorth A (2012) Probing pore characteristics of deformed chalk by NMR relaxation. J Petrol Sci Eng 100:123130. https://doi.org/10.1016/j.petrol.2012.11.001

Merritt JW, Auton CA (2000) An outline of the lithostratigraphy and depositional history of quaternary deposits in the Sellafield district, West Cumbria. Proc York Geol Soc 53:129-154. https://doi.org/10. 1144/pygs.53.2.129

Michael HA, Voss CI (2009) Controls on groundwater flow in the Bengal Basin of India and Bangladesh: regional modeling analysis. Hydrogeol J 17:1561-1577. https://doi.org/10.1007/s10040-0080429-4

Michalzik D (1991) Facies sequence of Triassic-Jurassic red beds in the Sierra Madre Oriental (NE Mexico) and its relation to the early opening of the Gulf of Mexico. Sediment Geol 71:243-259. https://doi.org/10.1016/0037-0738(91)90105-M

Michie U (1996) The geological framework of the Sellafield area and its relationship to hydrogeology. Q J Eng Geol Hydrogeol 29:13-27. https://doi.org/10.1144/GSL.QJEGH.1996.029.S1.02

Milodowski AE, Gillespie MR, Naden J, Fortey NJ, Shepherd TJ, Pearce JM, Metcalfe R (1998) The petrology and paragenesis of fracture mineralization in the Sellafield area, West Cumbria. Proc York Geol Soc 52:215-241. https://doi.org/10.1144/pygs.52.2.215

Min KB, Jing L, Stephansson O (2004) Determining the equivalent permeability tensor for fractured rock masses using a stochastic REV approach: method and application to the field data from Sellafield, UK. Hydrogeol J 12:497-451. https://doi.org/10.1007/s10040-0040331-7

Molz FJ, Morin RH, Hess AE, Melville JG, Güven O (1989) The impeller meter for measuring aquifer permeability variations: evaluation and comparison with other tests. Water Resour Res 25:1677-1683. https://doi.org/10.1029/WR025i007p01677

Morin RH, Carleton GB, Poirier S (1997) Fractured-aquifer hydrogeology from geophysical logs, the Passaic formation, New Jersey. Groundwater 35:328-338. https://doi.org/10.1111/j.1745-6584. 1997.tb00090.x

Morriss C, Rossini D, Straley C, Tutunjian P, Vinegar H (1997) Core analysis by low-field NMR. Log Analyst 38:84-94

Moss PD, Edmunds WM (1992) Processes controlling acid attenuation in the unsaturated zone of a Triassic sandstone aquifer (UK), in the absence of carbonate minerals. Appl Geochem 7:573-583. https:// doi.org/10.1016/0883-2927(92)90072-B

Mountney NP, Thompson DB (2002) Stratigraphic evolution and preservation of aeolian dune and damp/wet interdune strata: an example from the Triassic Helsby sandstone formation, Cheshire Basin, UK. Sedimentology 49:805-833. https://doi.org/10.1046/j.1365-3091. 2002.00472.x

Neuman SP (1975) Analysis of pumping test data from anisotropic unconfined aquifers considering delayed gravity response. Water Resour Res 11:329-342. https://doi.org/10.1029/WR011i002p00329

Nguyen BT, Jones SJ, Goulty NR, Middleton AJ, Grant N, Ferguson A, Bowen L (2013) The role of fluid pressure and diagenetic cements for porosity preservation in Triassic fluvial reservoirs of the central Graben, North Sea. AAPG Bull 97:1273-1302

Nirex (1992a) Liquid permeability-gas permeability correlation for Permo-Trias samples from Sellafield boreholes Nos 235 and 7. Nirex report 226. British Geological Survey, Nottingham, UK

Nirex (1992b) The geology and hydrogeology of Sellafield. NIREX report 263. British Geological Survey, Nottingham, UK

Nirex (1992c) Permeability and porosity results for samples from the Permo-Trias carboniferous and Borrowdale volcanic Group of Sellafield Borehole 10. Nirex report 226. British Geological Survey, Nottingham, UK

Nirex (1993a) The geology and hydrogeology of the Sellafield area: interim assessment. Nirex report 524. British Geological Survey, Nottingham, UK

Nirex (1993b) Permeability and porosity results for samples from the Permo-Trias and Borrowdale volcanic Group of Sellafield Borehole RCF3 and the Permo-Trias of Sellafield borehole RCM2. Nirex report 806. British Geological Survey, Nottingham, UK

Nirex (1993c) Permeability and porosity results for samples from the Permo-Triassic and carboniferous of Sellafield boreholes 13A 13B 14A RCF1 and RCF2. Nirex report 818. British Geological Survey, Nottingham, UK

Nirex (1996a) Geological Core logs 500 mbRT to 1000 mbRT. Nirex report 107. British Geological Survey, Nottingham, UK

Nirex (1996b) Geological Core logs $500 \mathrm{mbRT}$ to $1000 \mathrm{mbRT}$. Nirex report 108. British Geological Survey, Nottingham, UK

Nirex (1997) Sellafield geological and hydrogeological investigations: sedimentology and sedimentary architecture of the St Bees 
sandstone formation in West Cumbria. Report SA/97/023. British Geological Survey, Nottingham, UK

Nirex (2001) Laboratory measurements of the mass transfer properties of samples from the Permo-Triassic strata from Cumbria. Report NSS/ R278. British Geological Survey, Nottingham, UK

Noushabadi MJ, Jourde H, Massonnat G (2011) Influence of the observation scale on permeability estimation at local and regional scales through well tests in a fractured and karstic aquifer (Lez aquifer, southern France). J Hydrol 403:321-336. https://doi.org/10.1016/j. jhydrol.2011.04.013

Odling NE, Gillespie P, Bourgine B, Castaing C, Chiles JP, Christensen NP, Fillion E, Genter A, Olsen C, Thrane L, Trice R (1999) Variations in fracture system geometry and their implications for fluid flow in fractured hydrocarbon reservoirs. Pet Geosci 5:373384. https://doi.org/10.1144/petgeo.5.4.373

Odling NE, West LJ, Hartmann S, Kilpatrick A (2013) Fractional flow in fractured chalk: a flow and tracer test revisited. J Contam Hydrol 14: 96-111. https://doi.org/10.1016/j.jconhyd.2013.02.003

Olivarius M, Nielsen LH (2016) Triassic paleogeography of the greater eastern Norwegian-Danish basin: constraints from provenance analysis of the Skagerrak formation. Marine Petrol Geol 69:168-182. https://doi.org/10.1016/j.marpetgeo.2015.10.008

Olivarius M, Weibel R, Hjuler ML, Kristensen L, Mathiesen A, Nielsen LH, Kjøller C (2015) Diagenetic effects on porosity-permeability relationships in red beds of the lower Triassic bunter sandstone formation in the north German Basin. Sed Geol 321:139-153. https://doi.org/10.1016/j.sedgeo.2015.03.003

Paillet FL (1998) Flow modeling and permeability estimation using borehole flow logs in heterogeneous fractured formations. Water Resour Res 345:997-1010. https://doi.org/10.1029/98WR00268

Paillet (2001) Hydraulic head applications of flow logs in the study of heterogeneous aquifers. Groundwater 39:667-675. https://doi.org/ 10.1111/j.1745-6584.2001.tb02356.x

Paradis, D, Tremblay, L, Lefebvre, R, Gloaguen, E, Rivera, A, Parent, M, Ballard, JM, Michaud, Y, Brunet, P (2014) Field characterization and data integration to define the hydraulic heterogeneity of a shallow granular aquifer at a sub-watershed scale. Environ Earth Sci 72(5):1325-1348. doi:https://doi.org/10.1007/s12665-014-3318-2

Parker AH, West LJ, Odling NE, Bown RT (2010) A forward modeling approach for interpreting impeller flow logs. Groundwater 48:7991. https://doi.org/10.1111/j.1745-6584.2009.00600.x

Pokar M, West LJ, Odling NE (2006) Petrophysical characterization of the Sherwood Sandstone from East Yorkshire, UK. Geol Soc Lond Spec Publ 263(1):103-118. https://doi.org/10.1144/GSL.SP.2006. 263.01 .05

Ran G, Shalev E, Yechieli Y, Sagy A, Weisbrod N (2014) The permeability of fault zones: a case study of the Dead Sea rift (Middle East). Hydrogeol J 22:425-440. https://doi.org/10.1007/s10040-0131055-3

Rivett MO, Turner RJ, Glibbery CMO (2012) The legacy of chlorinated solvents in the Birmingham aquifer, UK: observations spanning three decades and the challenge of future urban groundwater development. J Contam Hydrol 140:107-123. https://doi.org/10.1016/j. jconhyd.2012.08.006

Ruggeri G, Gianelli G (1999) Multi-stage fluid circulation in a hydraulic fracture breccia of the Larderello geothermal field (Italy). J Volcanol Geotherm Res 90:241-261. https://doi.org/10.1016/S0377-0273 (99)00030-X

Runkel AC, Tipping RG, Alexander EC, Alexander SC (2006) Hydrostratigraphic characterization of intergranular and secondary porosity in part of the Cambrian sandstone aquifer system of the cratonic interior of North America: improving predictability of hydrogeologic properties. Sediment Geol 184:281-304. https://doi. org/10.1016/j.sedgeo.2005.11.006

Rustichelli A, Agosta F, Tondi SV (2013) Spacing and distribution of bed-perpendicular joints throughout layered, shallow-marine carbonates (Granada Basin, southern Spain). Tectonophysics 582: 188-204. https://doi.org/10.1016/j.tecto.2012.10.007

Rustichelli A, Di Celma C, Tondi E, Bianucci G (2016) Deformation within the Pisco basin sedimentary record (southern Peru): stratabound orthogonal vein sets and their impact on fault development. J South Am Earth Sci 65:79-100. https://doi.org/10.1016/j. jsames.2015.11.002

Sadooni FN, Alsharhan AS (2004) Stratigraphy, lithofacies distribution, and petroleum potential of the Triassic strata of the northern Arabian plate. AAPG Bull 88:515-538

Selley RC (1978) Porosity gradients in North Sea oil-bearing sandstones. J Geol Soc 135:119-132. https://doi.org/10.1144/gsjgs.135.1.0119

Streetly MC, Chakrabarty C, McLeod R (2000) Interpretation of pumping tests in the Sherwood Sandstone Group, Sellafield, Cumbria, UK. Q J Eng Geol Hydrogeol 33:281-299. https://doi.org/10.1144/qjegh. 33.4.281

Strong GE, Milodowski AE, Pearce JM, Kemp SJ, Prior SV, Morton AC (1994) The petrology and diagenesis of Permo-Triassic rocks of the Sellafield area, Cumbria. Proc York Geol Soc 50:77-89. https://doi. org/10.1144/pygs.50.1.77

Sutton JS (1996) Hydrogeological testing in the Sellafield area. Q J Eng Geol Hydrogeol 29:29-38. https://doi.org/10.1144/GSL.QJEGH. 1996.029.S1.03

Tellam JH (2004) 19th century studies of the hydrogeology of the PermoTriassic sandstones of the northern Cheshire Basin, England. Geol Soc Lond Spec Publ 225:89-105. https://doi.org/10.1144/GSL.SP. 2004.225.01.07

Tellam JH, Barker RD (2006) Towards prediction of saturated-zone pollutant movement in groundwaters in fractured permeable-matrix aquifers: the case of the UK Permo-Triassic sandstones. Geol Soc Lond Spec Publ 263:1-48. https://doi.org/10.1144/GSL.SP.2006. 263.01.01

Theis CV (1935) The relation between the lowering of the piezometric surface and the rate and duration of discharge of a well using groundwater storage. Trans Am Geophys Union 16:519-524. https://doi.org/10.1029/TR016i002p00519

Thompson DB (1970) Sedimentation of the Triassic (Scythian) red pebbly sandstones in the Cheshire Basin and its margins. Geol J 7:183216. https://doi.org/10.1002/gj.3350070111

Toccalino PL, Norman JE, Hitt KJ (2010). Quality of source water from public-supply wells in United States, 1993-2007. US Geol Surv Sci Invest Rep 2010-5024

Tratman EK (1967) The caves of Northwest Clare, Ireland. The University of Bristol Spelaeological Society, David and Charles, Newton Abbot, UK

Truesdell AH, White DE (1973) Production of superheated steam from vapor-dominated geothermal reservoirs. Geothermics 2:154-173. https://doi.org/10.1016/0375-6505(73)90022-9

Tsang CF, Barnichon JD, Birkholzer J, Li XL, Liu HH, Sillen X (2012) Coupled thermo-hydro-mechanical processes in the near field of a high-level radioactive waste repository in clay formations. Int $\mathrm{J}$ Rock Mech Mining Sci 49:31-44. https://doi.org/10.1016/j. ijrmms.2011.09.015

Tsang CF, Rosberg JE, Sharma P, Berthet T, Juhlin C, Niemi A (2016) Hydrologic testing during drilling: application of the flowing fluid electrical conductivity (FFEC) logging method to drilling of a deep borehole. Hydrogeol J 24:1333-1341. https://doi.org/10.1007/ s10040-016-1405-Z

Turner P (1981) Relationship between magnetic components and diagenetic features in reddened Triassic alluvium (St Bees Sandstone, Cumbria, UK). Geophys J Intern 67:395-413. https://doi.org/10. 1111/j.1365-246X.1981.tb02757.x

Vignaroli G, Aldega L, Balsamo F, Billi A., De Benedetti AA, De Filippis L, Giordano G, Rossetti F (2015). A way to hydrothermal paroxysm, Colli Albani volcano, Italy. Geol Soc Am Bull 127(5-6):672-687. doi:https://doi.org/10.1130/B31139.1 
Voss CI, Andersson J (1993) Regional flow in the Baltic shield during Holocene coastal regression. Groundwater 31:989-1006. https://doi. org/10.1111/j.1745-6584.1993.tb00873.x

Walker TR (1967) Formation of red beds in modern and ancient deserts. Geol Soc Am Bull 78:353-368. https://doi.org/10.1130/0016-7606

Waugh B (1973) The distribution and formation of Permo-Triassic red beds. Petroleum Geol Mem 2:678-693

Waugh B (1978) Authigenic K-feldspar in British Permo-Triassic sandstones. J Geol Soc 135:51-56. https://doi.org/10.1144/gsigs.135.1. 0051

Wealthall GP, Steele A, Bloomfield JP, Moss RH, Lerner DN (2001) Sediment filled fractures in the Permo-Triassic sandstones of the Cheshire Basin: observations and implications for pollutant transport. J Contam Hydrol 50:41-51. https://doi.org/10.1016/S01697722(01)00104-8
Weibel R (1998) Diagenesis in oxidising and locally reducing conditions: an example from the Triassic Skagerrak formation, Denmark. Sediment Geol 121:259-276. https://doi.org/10.1016/S00370738(98)00085-2

Weibel R, Friis H (2004) Opaque minerals as keys for distinguishing oxidising and reducing diagenetic conditions in the lower Triassic bunter sandstone, north German Basin. Sediment Geol 169:129-149

Worthington SRH, Gareth J, Alexander EC (2016) Enhancement of bedrock permeability by weathering. Earth-Sci Rev 160:188-202. https://doi.org/10.1016/j.earscirev.2016.07.002

Ziegler PA (1982) Triassic rifts and facies patterns in Western and Central Europe. Geol Rundsch 71:747-772. https://doi.org/10.1007/ BF01821101

Zheng SY, Corbett PW, Ryseth A, Stewart G (2000) Uncertainty in well test and core permeability analysis: a case study in fluvial channel reservoirs, northern North Sea, Norway. AAPG Bull 84:1929-1954 